\title{
GARANTIA DOS DIREITOS FUNDAMENTAIS FRENTE AO TRÁFICO HUMANO E AO TRABALHO ESCRAVO - DIREITO AO TRABALHO ${ }^{1}$
}

\section{Marco Antônio César Villatore}

Advogado. Pós-Doutor em Direito pela Universidade de Roma II (Uniroma II - Tor Vergata, Itália). Doutor pela Universidade de Roma I (Uniroma I - La Sapienza, Itália), revalidado pela Universidade Federal de Santa Catarina, Florianópolis (UFSC). Mestre pela Pontifícia Universidade Católica de São Paulo, São Paulo (PUC/SP). Professor Adjunto III do Departamento de Direito da Universidade Federal de Santa Catarina, Florianópolis (UFSC). Professor do Centro Universitário Internacional (Uninter Educacional S.A.), Campus Curitiba, Paraná. Professor Titular do Curso de Mestrado e de Doutorado em Direito da Pontifícia Universidade Católica do Paraná, Curitiba (PUCPR). Líder do Grupo de Pesquisa “Desregulamentação do Direito, do Estado e Atividade Econômica: Enfoque Laboral”. E-mail: <marcovillatore@gmail.com>.

\section{Juliana Wülfing}

Doutora em Direito pelo Programa de Pós-Graduação em Direito da Universidade Federal de Santa Catarina, Florianópolis (UFSC). Mestre em Direito pela Universidade do Vale dos Sinos, São Leopoldo (Unisinos). Professora Adjunta do Departamento de Direito da Universidade Federal de Santa Catarina, Florianópolis (UFSC). E-mail: <wulfing@hotmail.com>.

\begin{abstract}
Resumo: 0 objeto do estudo é o tráfico humano e o trabalho escravo frente à garantia dos direitos fundamentais, tendo como objetivo verificar a sua real situação em relação aos problemas sociais e às questões legislativas. A metodologia escolhida foi a indutiva-bibliográfica-documental. 0 tráfico de pessoas com intuito de exploração para o trabalho escravo é uma agressão à dignidade humana, uma negação aos direitos fundamentais e um desrespeito ao Estado Democrático de Direito, prática que tem preocupado as sociedades nacionais e os organismos internacionais de forma similar. É preciso enfrentar essa "chaga" não esquecida, e, então, conscientizar a sociedade da necessidade de eliminar as formas de discriminação, enfrentar os problemas da prostituição, promover o trabalho decente, criar políticas migratórias com responsabilidade, visando ao direito ao trabalho. É importante o desenvolvimento de políticas públicas que pretendam a efetivação dos direitos fundamentais e a transformação das estruturas sociais, visando a uma sociedade justa e igualitária.
\end{abstract}

Palavras-chave: Direitos fundamentais. Tráfico humano. Trabalho escravo. Direito ao trabalho.

1 Agradecemos ao Dr. Glaucio Araujo de Oliveira, Procurador do Trabalho do Ministério Público do Trabalho do Paraná - 9a Região, atualmente Procurador-Chefe, pelo fornecimento de importante material escrito e do relato de situações reais, pois já prestou serviços em várias regiões do Brasil, principalmente no Norte (Pará), retirando seres humanos de situações de trabalho escravo. 
Sumário: 1 Introdução - $\mathbf{2}$ Tráfico humano e trabalho escravo - "Chaga" não esquecida - $\mathbf{3}$ Direitos humanos, direitos fundamentais, questões legislativas e jurisprudenciais - $\mathbf{4}$ Considerações finais Referências

\section{Introdução}

0 direito, historicamente, tem sido o ponto de amparo para o encontro de alternativas de efetivação da justiça, de soluções de conflitos, da busca do equilíbrio das ideologias, da luta pelas liberdades e garantias, da resistência e da emancipação do ser humano.

Os direitos fundamentais, nascidos para garantir a dignidade da pessoa humana, conquistaram espaços e honrarias na contemporaneidade, porém, a efetivação dessas garantias também deve chegar aos marginalizados e aos excluídos.

Os direitos humanos, ao serem positivados pelo ordenamento jurídico de determinado país, são denominados direitos fundamentais, constituindo estes os direitos positivados pelo Estado com a finalidade de consagrar ou de enaltecer valores já reconhecidos internacionalmente como essenciais para promover a dignidade humana.

Os direitos fundamentais se encontram sujeitos a alterações em relação ao conteúdo, à titularidade e à eficácia de acordo com a evolução histórica de cada Estado. Apesar de inerentes à própria condição humana, a proteção surge através de um processo histórico de luta pelo reconhecimento.

O tráfico humano e o trabalho escravo ou em situação análoga à de escravo afrontam os princípios e as garantias individuais da Declaração dos Direitos Humanos e da Constituição de 1988, constituindo-se em ofensa ao Estado Democrático de Direito, à vida e à dignidade da pessoa humana. São temas muito estudados e discutidos, mas que continuam relevantes e atuais por ainda permanecerem como uma "chaga" social.

O combate ao tráfico de pessoas e ao trabalho escravo ou em situação análoga à escravidão será analisado também pelos pontos de vista do fenômeno social e das categorias jurídico-normativas envolvidas.

Para o estudo do tema proposto, o presente trabalho foi dividido em duas partes. A primeira trata do tráfico humano e do trabalho escravo como uma "chaga" não esquecida e, o segundo, dos direitos fundamentais, inclusive do direito ao trabalho, e das questões legislativas. 


\title{
2 Tráfico humano e trabalho escravo - "Chaga" não esquecida
}

Antes de se analisar o trabalho escravo, convém explicar que o trabalho forçado é o gênero do qual o primeiro é uma das espécies, podendo ser também um trabalho obrigatório, como alistamento militar, como se abordará na segunda parte deste trabalho, no comentário à Convenção no 29 da Organização Internacional do Trabalho.

Segundo o Manual de combate ao trabalho em condições análogas às de escravo, produzido pelo Ministério do Trabalho: ${ }^{2}$

\begin{abstract}
Diversas são as denominações dadas ao fenômeno de exploração ilícita e precária do trabalho, ora chamado de trabalho forçado, trabaIho escravo, exploração do trabalho, semiescravidão, trabalho degradante, entre outros, que são utilizados indistintamente para tratar da mesma realidade jurídica. Malgrado as diversas denominações, qualquer trabalho que não reúna as mínimas condições necessárias para garantir os direitos do trabalhador, ou seja, cerceie sua liberdade, avilte a sua dignidade, sujeite-o a condições degradantes, inclusive em relação ao meio ambiente de trabalho, há que ser considerado trabalho em condição análoga a de escravo.
\end{abstract}

O tráfico humano envolve organizações mundiais criminosas que visam ludibriar pessoas para as encarcerar como escravas com o intuito de explorar a força de trabalho, ligado ao direito fundamental ao trabalho, e/ou à sexualidade, ou ainda, remover e comercializar órgãos, explorar pelo tráfico de drogas, entre outros.

Os traficantes, fazendo uso da boa-fé, da ingenuidade e de promessas de ganhos financeiros fáceis, convencem os traficados de que, em outros países ou nos grandes centros urbanos, há maiores oportunidades de empregos, de ascenderem na carreira, de se profissionalizarem, de serem pagos em moedas mais fortes, como euros ou dólares, e de voltarem para o país/cidade de origem com economias suficientes para abrirem seu próprio negócio, ajudarem os familiares ou resolverem suas questões financeiras, pelo menos momentaneamente.

Note-se prática do trabalho escravo em um depoimento:

BRASIL. Ministério do Trabalho e Emprego. Manual de combate ao trabalho em condições análogas às de escravo. Brasília: Ministério do Trabalho e Emprego, 2011. Disponível em: <http://www.mpf. $\mathrm{mp}$.br/atuacao-tematica/ccr2/coordenacao/comissoes-e-grupos-de-trabalho/escravidao-contemporaneamigrado-1/notas-tecnicas-planos-e-oficinas/combate\%20trabalho\%20escravo\%20WEB\%20MTE.pdf>. Acesso em: 7 set. 2017. 
naquela época era mais difícil serviço aqui. Então, chegou um cara, foi na rua e aí anunciou que queria 42 peão (sic). Em Imperatriz, nós cheguemos (sic) lá e nós fumos (sic) vendido (sic)! Oitenta reais pra ( sic) cada cabeça, os 42. Quando deu com 25 dias [de trabalho] eu falei pro (sic) gato: Barroso, eu quero um dinheiro para mandar pra ( sic) a minha família em casa, porque lá não ficou nada; vocês não me deram nada. Ele disse: "Hum, rapariga de filha de uma égua nenhum desses que têm aqui não vai (sic) ver nenhum dinheiro. Tirando antes de 90 dias não vai nenhum dinheiro pra ( sic) essas raparigas de vocês na rua". Quando completou 30 dias eu disse: meninos, quem quiser ir embora mais eu ( $\mathrm{sic}$ ), nós vamos. Aí o cantineiro avisou nós (sic): "rapaz, não sai de nenhum de vocês; se saírem vocês morrem. Tem muito jagunço na fazenda". Nessas alturas, tinha um rapaz de Chapadinha. Nós escutemos (sic) os tiros. Seis horas. E esse rapaz, até hoje, nunca mais voltou. ${ }^{3}$

Assim, após quase 125 anos da publicação da Lei Áurea (Lei no 3.353, de 13.5.1888), que aboliu formalmente a condição jurídica da escravatura no Brasil, percebe-se que há muito a ser feito para que tal fato tenha plena eficácia, porque não se passa impunemente pelo fato de ter sido a última nação a abolir o cativeiro, já que até maio de 1888 era possível garantir a posse de um ser humano por outro. Era difícil a convivência entre o projeto republicano - que, recém-inaugurado em novembro de 1889, vendia uma imagem de modernidade - e a lembrança recente do sistema escravocrata, que levava à conformação de uma sociedade patriarcal, marcada pelas relações de ordem pessoal, violenta e na qual vigorava um profundo preconceito em relação ao trabalho braçal. ${ }^{4}$

A preocupação com o combate do trabalho escravo, no Brasil, de forma sistemática, ocorre desde 1995, quando foi criado um grupo móvel de fiscalização, coordenado pelo Ministério do Trabalho e Emprego - MTE, atualmente Ministério do Trabalho, formado por equipes de juízes, de promotores e de Delegacias Regionais do Trabalho, agora denominadas Superintendências Regionais do Trabalho, entre outros, sendo que estas equipes libertaram, desde então, cerca de 23 mil pessoas do cativeiro e garantiram a elas o pagamento dos direitos trabalhistas devidos. Essas ações são a base de processos judiciais contra os

MINISTÉRIO DA JUSTIÇA. Política Nacional de Enfrentamento ao Tráfico de Pessoas. Brasília: Ministério da Justiça, 2007. p. 44. Disponível em: <http://reporterbrasil.org.br/documentos/cartilha_trafico_pessoas. pdf>. Acesso em: 30 ago. 2017.

4 COSTA, Ângela Marques da; SCHWARCZ, Lilia Moritz. 1890 - 1914: no tempo das certezas. São Paulo: Companhia das Letras, 2000. p. 19. 
empregadores, como cadastro de empregadores que utilizaram trabalho escravo, atualizado semestralmente pelo Ministério do Trabalho.

Com base na chamada "Lista suja", os proprietários rurais têm perdido empréstimos em instituições financeiras e clientes, uma vez que os signatários do Pacto Nacional pela Erradicação do Trabalho Escravo firmaram o compromisso de não comprar de fazendas flagradas com a prática. Ao mesmo tempo, o Ministério do Desenvolvimento Agrário e o Incra têm verificado a legalidade dos títulos dessas propriedades. ${ }^{5}$

Apesar da proibição de trabalho análogo ao de escravo, da fiscalização, dos trabalhos de entidades de classes e das organizações governamentais para coibir a prática, o trabalho escravo ainda é uma realidade no país. Em 2003, o Brasil foi obrigado, perante a Corte Internacional de Direitos Humanos, a reconhecer e a assumir a sua responsabilidade frente ao caso José Pereira:

A motivação para o reconhecimento feito pelo Presidente Luis Inácio Lula da Silva adveio do fato de um trabalhador brasileiro, José Pereira, de 17 anos, ter sido alvejado por arma de fogo, em setembro de 1989, quando da tentativa de evasão de cativeiro existente na Fazenda Espírito Santo, localizada no Estado do Pará, onde era mantido com outros 60 colegas para a prestação de serviços em condições análogas à de escravidão. No evento, o trabalhador sofreu ferimentos em uma das mãos e em um dos olhos, ocasionando-lhe sequelas permanentes, tendo seu colega, de alcunha "Paraná", perdido a vida. Os criminosos não foram punidos em decorrência da prescrição retroativa, já que houve o transcurso do tempo previsto para o término do Inquérito Policial e o oferecimento da denúncia ao Judiciário. A impunidade gerou a denúncia junto à Corte Interamericana, o que provocou a entabulação de um acordo com esta, através do qual o Brasil se comprometeria a adotar medidas de combate à mortalidade de trabalho escravo contemporâneo em seu território. Desse compromisso origina-se o primeiro Plano Nacional para a Erradicação do Trabalho Escravo. ${ }^{6}$

Apesar das iniciativas nacionais, somente em 8.3.2004, em Genebra, Suíça, na Reunião na Organização das Nações Unidas (ONU), admitiu a existência de

5 MINISTÉRIO DA JUSTIÇA. Política Nacional de Enfrentamento ao Tráfico de Pessoas. Brasília: Ministério da Justiça, 2007. p. 19. Disponível em: <http://reporterbrasil.org.br/documentos/cartilha_trafico_pessoas. pdf>. Acesso em: 30 ago. 2017.

6 FÁVERO FILHO, Nicanor. Trabalho escravo: vilipendio à dignidade humana. In: PIOVESAN, Flavia; CARVALHO, Luciana Paula Vaz de (Org.). Direitos humanos e direito do trabalho. São Paulo: Atlas, 2010. p. 259. 
trabalho escravo em seu território perante referidos membros, mesmo assim, foi a primeira nação a adotar esta postura na ONU.

Nesta oportunidade, o Embaixador brasileiro Tadeu Valadares, então Chefe da Divisão de Direitos Humanos do Itamaraty, afirmou que 5.400 (cinco mil e quatrocentos) trabalhadores foram resgatados em 2003 e que cerca de 25.000 (vinte e cinco mil) ainda se encontravam em situação análoga à de escravo.

Questionamos o Professor Doutor Matteo Carbonelli, da Università per Stranieri di Perugia e da Università degli studi di Roma I, Sapienza, ambas na Itália, representante de direitos humanos junto à Ordem dos Advogados italiana e Diretor da Revista de Direitos Humanos, com o qual debatemos o tema dos direitos fundamentais e o trabalho, no Seminário Ítalo-Brasileiro de Direito do Trabalho, ocorrido na Universidade Federal de Santa Catarina, em 29.3.2004, evento itinerante, que também ocorreu na Pontifícia Universidade Católica do Paraná e nos Tribunais Regionais do Trabalho de Campinas e do Rio de Janeiro, sobre a importância do reconhecimento do governo brasileiro da existência de trabalho escravo em seu território, perante o cenário mundial. ${ }^{7}$ Referido painelista frisou que tal fato somente vem a demonstrar a intenção brasileira para se chegar à total erradicação do trabalho forçado, devendo ser copiado por tantas outras nações que possuem situações similares ou até piores em relação ao Brasil.

A preocupação mundial com o tráfico de pessoas teve início com a discussão ocorrida na ONU, que culminou com a aprovação do Protocolo de Palermo, na cidade de Palermo, Itália, no ano de 2000. O Protocolo de Palermo pretende a prevenção, supressão e punição do tráfico de pessoas, especialmente de mulheres e crianças, que constituem o grupo mais vulnerável. ${ }^{8}$

O membro do Comitê de Peritos da Organização Internacional do Trabalho e também Ministro do Tribunal Superior do Trabalho, Lélio Bentes Corrêa, ${ }^{9}$ participou de audiência pública e explicou que o trabalho escravo não é caracterizado

\footnotetext{
“A instituição de um direito mantém acesa a perspectiva, mais ou menos utópica, de que a realização de determinadas condições necessárias percebidas como ausentes (necessidades como manque) possam ser racionalmente perseguidas do ponto de vista prático (necessidades como projet), prevenindo contra o abandono de aspirações que, por falta de reconhecimento público, podem ser consideradas impossíveis ou, pior, indesejáveis, como ilustrado na célebre parábola de Escopo da raposa e as uvas verdes. É claro que as condições materiais necessárias de realização têm, aí, um peso muito maior. Mas não se pode negligenciar a relevância específica da institucionalização de direitos fundamentais como um dos mecanismos necessários a essa realização" (WANDELLI, Leonardo Vieira. O direito humano e fundamental ao trabalho. Fundamentação e exigibilidade. São Paulo: LTr, 2012. p. 189).

8 SOUZA, Mércia Cardoso de; SILVA, Laura Cristina Lacerda e. Algumas reflexões sobre o enfrentamento ao tráfico de pessoas no Brasil. Âmbito Jurídico. p. 1. Disponível em: <www.ambito-juridico.com.br/site/ index.php?n_link=revista_artigo_leitura\&artigo_id=9302>. Acesso em: 30 ago. 2017.

9 RODRIGUES, Vânia. Trabalho escravo: parecer será favorável ao confisco das terras. UITA - Secretaría Regional Latinoamericana, Montevideo, 5 abr. 2004. Disponivel em: <http://www6.rel-uita.org/ internacional/trabalho_escravo.htm>. Acesso em: 30 ago. 2017.
} 
pela ausência de formalismo, na contratação dos empregados, como exemplo, assinatura da Carteira de Trabalho, mas "são determinadas características, como as condições de trabalho, o confinamento, a falta de equipamentos de trabalho, a vigilância armada, a impossibilidade de retorno à cidade de origem e a retenção de pagamentos e documentos que confirmam o regime de escravidão", sendo favorável à aprovação de uma emenda constitucional.

Em razão da vastidão do território brasileiro, é mais difícil fiscalizar o trabalho escravo ou situações análogas à de escravidão, que ocorrem em todos os estados, mas com maior incidência em madeireiras do sul do Pará e parte do Amazonas, além dos estados de Pernambuco, Mato Grosso e Tocantins. ${ }^{10}$

Apesar de ser mais comum em grandes propriedades, longe dos centros urbanos, tal prática também existe em área urbana, normalmente com estrangeiros em situação irregular trabalhando na confecção e na venda de vestuários e de produtos piratas, mas também em casas de prostituição, ligadas a hotéis e pousadas variadas, inclusive algumas em que todas as acomodações são direcionadas exclusivamente para esse fim, sendo comercializadas por hora de permanência, onde são explorados, além de adultos, crianças e adolescentes. ${ }^{11}$

Muitos desses locais agregam trabalhadores que estão ali sob tortura, escravizados por dívidas de viagem e/ou de alimentação (truck sistem), os quais não podem denunciar seus agressores sob risco de serem mutilados ou de perderem suas vidas e, pior, sob ameaças à integridade de seus familiares e entes queridos, ${ }^{12}$ sendo que:

10 “A estimativa é de que dois terços dos trabalhadores brasileiros encontrados em situação de trabalho escravo no Pará, Maranhão e Mato Grosso sejam oriundos do Nordeste, com destaque para o Piauí e o Maranhão, Bahia e Ceará. Não é por acaso" (MINISTÉRIO DA JUSTIÇA. Política Nacional de Enfrentamento ao Tráfico de Pessoas. Brasília: Ministério da Justiça, 2007. p. 17. Disponível em: <http://reporterbrasil. org.br/documentos/cartilha_trafico_pessoas.pdf>. Acesso em: 30 ago. 2017).

11 “A exploração do trabalho infantil e representa um dos problemas mais alarmantes do cenário mundial, afetando vários países e mostrando-se mais evidente em países subdesenvolvidos e em nações em vias de desenvolvimento, entre elas, o Brasil. O combate ao trabalho infantil e a criação de mecanismos que visem à correta formação de crianças e adolescentes é função da sociedade, da família e, sobretudo, do Estado, porquanto crianças e adolescentes não podem ser inseridas no mundo do trabalho sem antes ter o direito de vivenciarem o período mais terno e importante de suas vidas, que será determinante para a construção do seu caráter e da sua personalidade. A prática do trabalho infanto-juvenil fere a dignidade da criança e do adolescente, impede o livre exercício de seus direitos fundamentais constitucionalmente assegurados, fomenta a desigualdade social, conspira contra uma sociedade livre, democrática, solidária e cidadã, cujo cenário não podemos compactuar" (CARVALHO, Luciana Paula Vaz de. A violação à dignidade da criança e do adolescente no trabalho infantil. Normas e ações de proteção. In: PIOVESAN, Flavia; CARVALHO, Luciana Paula Vaz de (Org.). Direitos humanos e direito do trabalho. São Paulo: Atlas, 2010. p. 193-194).

12 “Todavia, o labor realizado sob a coordenação desse empreendedor ofende o princípio basilar do Estado Democrático de Direito: a dignidade da pessoa humana, pois submete o obreiro a condições ínfimas de sobrevivência, em patamar muito aquém do mínimo necessário para uma vida digna" (MIRAGLIA, Lívia Mendez Moreira. O combate ao trabalho escravo contemporâneo e a justiça do trabalho. In: SENA, Adriana 
a UNODC (Ofício da ONU sobre Drogas e Crime) estima em 140 mil, o número de pessoas - mulheres principalmente - traficadas e exploradas sexualmente em países da Europa. Entre elas, 13\% são sul-americanas. A Espanha é um dos principais destinos, seguida de Itália, Portugal, França, Holanda, Alemanha, Áustria e Suíça. Dentro do Brasil, uma pesquisa identificou 241 rotas de tráfico para fins de exploração sexual. Realizada em 2002, a Pesquisa Nacional sobre o Tráfico de Mulheres, Crianças e Adolescentes (PESTRAF) mapeou 241 rotas de tráfico de pessoas para fins de exploração sexual. Desse total, 131 rotas eram internacionais, 78 interestaduais e 32 intermunicipais.

Levantamento da Organização Internacional do Trabalho ${ }^{13}$ aponta que, de 20,9 milhões de trabalhadores forçados, em diferentes setores da economia,

- 18,7 milhões (90 por cento) são explorados na economia privada, por indivíduos ou empresas. Destes, 4,5 milhões (22 por cento) são vítimas de exploração sexual forçada e 14,2 milhões (68 por cento) são vítimas de exploração do trabalho forçado em atividades econômicas, como agricultura, construção civil, trabalho doméstico ou industrial.

- 2,2 milhões (10 por cento) estão em formas de trabalho forçado impostas pelo Estado, como por exemplo, nas prisões, o que viola as normas da OIT, ou impostas por forças armadas rebeldes ou exércitos nacionais.

Análise ainda mais preocupante é a que aponta a idade dos trabalhadores forçados: “5,5 milhões (26 por cento) estão abaixo de 18 anos, estimando que 22\% são enviados para o tráfico envolvendo exploração sexual; $74 \%$ seriam adultos e $26 \%$, crianças; e $55 \%$ seriam de mulheres contra $45 \%$ de homens". ${ }^{14}$

Outra forma de aliciamento de crianças e de adolescentes para o tráfico humano e o trabalho forçado está ligada ao rentável mundo futebolístico, que recruta menor, geralmente com a permissão dos pais e da sociedade, para jogar em

Goulart de; DELGADO, Gabriela Neves; NUNES, Raquel Portugal (Coord.). Dignidade humana e inclusão social. Caminhos para a efetivação do direito do trabalho no Brasil. São Paulo: LTr, 2010. p. 108).

1321 milhões de pessoas são vítimas de trabalho forçado no mundo. OIT, 1 jun. 2012. Disponível em: <http://www.oitbrasil.org.br/node/846>. Acesso em: 30 ago. 2017.

1421 milhões de pessoas são vítimas de trabalho forçado no mundo. OIT, 1ํjun. 2012. Disponível em: <http://www.oitbrasil.org.br/node/846>. Acesso em: 30 ago. 2017. 
outros países, porém, sem que Ihe sejam garantidos seus direitos fundamentais e sua dignidade ${ }^{15}$ como pessoa, assim:

O Tribunal de Justiça de São Paulo condenou a Portuguesa Santista a pagar indenização por tráfico de pessoas ao "recrutar menores de idade na região norte do País" para jogar futebol no clube, em Santos, litoral de São Paulo. O clube disputa a Série B do Campeonato Paulista. Cabe recurso. [...]

$\mathrm{O}$ acórdão menciona que doze garotos chegavam a se instalar em apartamento com menos de 40 metros quadrados, também sem assistência médica e odontológica, acompanhamento escolar e descanso semanal.

A condenação por tráfico de pessoas teve como base o Protocolo de Palermo, uma convenção da ONU contra o crime organizado, relativa a ( ic) prevenção, repressão e punição do tráfico de pessoas, especialmente mulheres e crianças. O clube e um empresário de futebol responsável pela vinda dos atletas serão obrigados a pagar a indenização, a ser fixada pela Justiça. ${ }^{16}$

Logo, os traficados para o trabalho escravo ou para a situação análoga à escravidão, ao chegarem ao local de trabalho, deparam-se com uma dura realidade: a remuneração, o trabalho e as acomodações não são aquelas prometidas pelo intermediador traficante. Ainda, além das péssimas condições de moradia e de alimentação, os valores cobrados são superfaturados, fazendo com que os trabalhadores não tenham condições de saldar suas dívidas, bem como estão em um local isolado, muitas vezes em outros países, com uma língua desconhecida,

15 “Afiançam-se duas dimensões da dignidade da pessoa humana - a individual e a social -, a fim de resgatar seu aspecto social, propositalmente esquecido pelo discurso neoliberal em voga. Entende-se que o ser humano só se realiza de maneira plena quando, além de respeitados seus direitos da personalidade (dimensão individual), conseguem inserir-se de fato em sua comunidade, garantindo a si e à sua família uma existência digna (dimensão social). É nesse contexto que se consolida o Direito do Trabalho como o principal - se não o único, com certeza, o mais eficaz - instrumento de concretização da dignidade social, pois é somente pelo trabalho digno que a pessoa alcança a realização plena como ser humano, uma vez que é por seu labor que o homem, destituído de riqueza, afirma-se na sociedade capitalista moderna" (MIRAGLIA, Lívia Mendez Moreira. O combate ao trabalho escravo contemporâneo e a justiça do trabalho. In: SENA, Adriana Goulart de; DELGADO, Gabriela Neves; NUNES, Raquel Portugal (Coord.). Dignidade humana e inclusão social. Caminhos para a efetivação do direito do trabalho no Brasil. São Paulo: LTr, 2010. p. 105-106).

16 ALICIAR jogadores é equiparado a traficar pessoas. Conjur, 11 dez. 2012. Disponível em: <http://www. conjur.com.br/2012-dez-11/tj-paulista-condena-portuguesa-santista-trafico-pessoas>. Acesso em: 30 ago. 2017. 
geralmente confinados em um local fortemente armado e com seus documentos pessoais confiscados. Estão verdadeiramente escravizados. ${ }^{17}$

É de se esperar que a sociedade, os políticos e os juristas despertem para garantirem-se os direitos fundamentais a toda a sociedade, para a conscientização dos cidadãos, para uma vigilância redobrada e para a prática de atos e esforços coletivos que tenham como objetivos erradicar a "chaga" do tráfico humano e do trabalho forçado ou em situação análoga à escravidão.

O tráfico humano e o trabalho escravo ou em situação análoga à escravidão afrontam os princípios e garantias individuais da Declaração dos Direitos Humanos e da Constituição brasileira. O presente estudo quer demonstrar a importância que se dá para problemática tão antiga, mas que infelizmente ainda não foi solucionada.

\section{Direitos humanos, direitos fundamentais, questões legislativas e jurisprudenciais}

Como já explicado, os direitos humanos, quando positivados pela Constituição de um país, são denominados direitos fundamentais.

Os direitos fundamentais se encontram sujeitos a alterações em relação ao conteúdo, à titularidade e à eficácia, de acordo com a evolução histórica de cada Estado. Apesar de inerentes à própria condição humana, a proteção surge de um processo histórico de alcance e luta pelo reconhecimento. ${ }^{18}$

Segundo Ingo Wolfgang Sarlet, as expressões "direitos humanos" e "direitos fundamentais" são distintas:

[...] o termo "direitos fundamentais" se aplica para aqueles direitos do ser humano reconhecidos e positivados na esfera do direito constitucional positivo de determinado Estado, ao passo que a expressão "direitos humanos" guardaria relação com os documentos de direito

\footnotetext{
17 “Ao Estado cabe proporcionar a todos os seus cidadãos acesso ao trabalho que permita o desenvolvimento de suas capacidades físicas e intelectuais, que proporcionem a estes a chance de se realizarem como pessoas, sendo sua obrigação, bem como de toda a sociedade, combater qualquer prática que possa despojar qualquer um de seus integrantes de sua dignidade.

O Brasil, ao possuir ainda trabalhadores prestando serviços em condições análogas à de escravos, não pode se outorgar o direito de ser reconhecido plenamente um Estado Democrático de Direito, pois a dignidade humana, que permeia todos os princípios de sua Constituição, não está sendo garantida, causando graves ranhuras aos direitos fundamentais e difusos [...]" (FÁVERO FILHO, Nicanor. Trabalho escravo: vilipendio à dignidade humana. In: PIOVESAN, Flavia; CARVALHO, Luciana Paula Vaz de (Org.). Direitos humanos e direito do trabalho. São Paulo: Atlas, 2010. p. 248).

18 BONAVIDES, Paulo. Curso de direito constitucional. 16. ed. São Paulo: Malheiros, 2005. p. 561.
} 
internacional, por referir-se àquelas posições jurídicas que se reconhecem ao ser humano como tal, independentemente de sua vinculação com determinada ordem constitucional, e que, portanto, aspiram à validade universal, para todos os povos e tempos, de tal sorte que revelam um inequívoco caráter supranacional (internacional). ${ }^{19}$

Existe uma diferenciação quanto ao aspecto internacional dos direitos humanos e à condição interna dos direitos fundamentais, entretanto, referidos termos costumam ser mencionados como sinônimos.

Diante do frequente uso indistinto das expressões, José Joaquim Gomes Canotilho já trazia a diferença entre direitos humanos e direitos fundamentais:

As expressões direitos do homem e direitos fundamentais são frequentemente utilizadas como sinônimas. Segundo a sua origem e significado poderíamos distingui-las da seguinte maneira: direitos do homem são direitos válidos para todos os povos e em todos os tempos; direitos fundamentais são os direitos do homem, jurídicoinstitucionalmente garantidos e limitados espacio-temporalmente. Os direitos do homem arrancariam da própria natureza humana e daí o seu caráter inviolável, intertemporal e universal; os direitos fundamentais seriam os direitos objetivamente vigentes numa ordem jurídica concreta. ${ }^{20}$

A característica da fundamentabilidade é conferida a determinados direitos mediante reconhecimento formal da Constituição de 1988 e também em razão do reconhecimento material, pois existem direitos que são fundamentais devido à imprescindibilidade para a tutela da dignidade humana, apesar da ausência de previsão constitucional explícita.

Os direitos fundamentais detêm eficácia direta e imediata. Tal afirmação significa a desnecessidade de legislação infraconstitucional para a aplicação desses direitos diante da máxima efetividade das normas constitucionais protetoras dos diversos aspectos da personalidade humana.

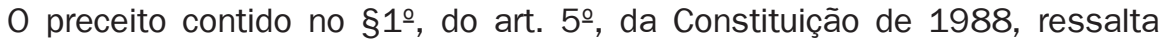
que normas definidoras de direitos fundamentais não são normas de caráter

19 SARLET, Ingo Wolfgang. A eficácia dos direitos fundamentais: uma teoria geral dos direitos fundamentais na perspectiva constitucional. 10. ed. Porto Alegre: Livraria do Advogado, 2009. p. 29.

20 CANOTILHO, José Joaquim Gomes. Direito constitucional e teoria da Constituição. 3. ed. Coimbra: Almedina, 1998. p. 259. 
meramente programático, mas normas que regulam relações jurídicas de modo direto.

As normas da Constituição que se refiram a direitos fundamentais podem e devem ser aplicadas diretamente para a solução de casos concretos, sendo desnecessária a atuação prévia do legislador infraconstitucional.

Trata-se do princípio da aplicabilidade imediata dos direitos e garantias fundamentais, o qual “investe os Poderes Públicos na atribuição constitucional de promover as condições para que os direitos e garantias fundamentais sejam reais e efetivos". ${ }^{21}$ Referida norma-princípio reflete a determinação de se conferir a maior eficácia possível aos direitos fundamentais. ${ }^{22}$

A Constituição brasileira garante aos brasileiros e estrangeiros uma série de direitos individuais e coletivos que visam a coibir o tráfico humano de pessoas e o trabalho forçado. Entre os direitos e garantias fundamentais, previstos no Título II da Carta Magna, encontram-se no Capítulo I os direitos e deveres individuais e coletivos, sendo que o art. 5ำ, caput, estabelece que todos são iguais e têm direito à vida e à liberdade, não sendo obrigados a fazer ou deixar de fazer algo, se não em virtude de lei (inc. II), sendo inadmissível que alguns se sintam proprietários de outros, limitando o seu direito de ir, vir e ser.

A Constituição de 1988 também proíbe a tortura, o tratamento desumano ou degradante (inc. III) e informa que é inviolável a honra, a intimidade, a vida privada (inc. X). Garante no art. 1ำ que a República Federativa do Brasil constitui um Estado Democrático de Direito, que tem como fundamento a soberania do Estado (inc. I), a dignidade da pessoa humana (inc. III) e os valores sociais do trabalho (inc. IV).

No $\S 1^{\circ}$, do art. 5을 estabelece que "as normas definidoras dos direitos e garantias fundamentais têm aplicação imediata”; e o §2ํㅜ, que os “[...] direitos a garantias expressos na Constituição não excluem outros decorrentes do regime e dos princípios por ela adotados, ou dos tratados internacionais em que a República Federativa do Brasil seja parte".

Enquanto isso, o Capítulo II, Dos Direitos e Garantias Fundamentais, prevê os direitos sociais, sendo que em seu art. 6얼 define que "são direitos sociais a educação, a saúde, a alimentação, o trabalho, a moradia, o lazer, a segurança, a previdência social, a proteção à maternidade e à infância, a assistência aos desamparados".

21 PIOVESAN, Flávia. Proteção judicial contra omissões legislativas. São Paulo: Revista dos Tribunais, 1995. p. 92.

22 SARLET, Ingo Wolfgang. A eficácia dos direitos fundamentais: uma teoria geral dos direitos fundamentais na perspectiva constitucional. 10. ed. Porto Alegre: Livraria do Advogado, 2009. p. 243-247. 
No art. 7으, estão definidos os direitos dos trabalhadores urbanos e rurais, como o seguro-desemprego (inc. II); o fundo de garantia por tempo de serviço (inc. III); o salário mínimo (inc. IV); a garantia da irredutibilidade do salário (inc. VII); o décimo terceiro salário (inc. VIII); o adicional noturno (inc. IX); a proibição de retenção dolosa do salário (inc. X); a duração do trabalho não superior a 8 horas diárias e 44 horas semanais (inc. XIII); o repouso semanal remunerado (inc. XV); a remuneração do trabalho extraordinário, no mínimo, 50\% superior ao normal (inc. $\mathrm{XVI}$ ); as férias (inc. XVII); a licença-gestante (inc. XVIII); a licença-paternidade (inc. $X I X)$, entre outros que visam a garantir a proteção dos trabalhadores.

Os direitos garantidos na Constituição de 1988 e na legislação esparsa se configuram como um mínimo existencial ao ser humano trabalhador, que é:

[...] o direito a satisfação das necessidades básicas, ou seja, direito a objetos, atividades e relações que garantem a saúde e a autonomia humana e, com isso, impedem a ocorrência de dano grave ou sofrimento em razão da deficiência de saúde ou impossibilidade de exercício da autonomia. ${ }^{23}$

A Declaração Universal dos Direitos Humanos, de 1948, aprovada pela Assembleia Geral das Nações Unidas, da qual o Brasil faz parte, em seu art. 4ํㅜ delibera que "ninguém será mantido em escravidão ou servidão; a escravidão e o tráfico de escravos estão proibidos e todas as suas formas"; o art. 23 garante a todos os homens o direito ao trabalho e condições justas de remuneração, e o art. 29 garante o direito à liberdade a todos os homens.

O tráfico de pessoas para o trabalho forçado se constitui em grave ofensa à Constituição brasileira, à vida e à dignidade da pessoa humana. É a configuração da coisificação humana, da falta de respeito, de solidariedade, de fraternidade e de humanidade para com seu igual.

Diversos são os fatores que ajudam a manter a escravidão no Brasil, tais como a pobreza, o desemprego provocado pela globalização e pela crise econômica, a modernização do campo, a falta de investimentos na agricultura familiar, a confiança dos infratores em sua impunidade, além de outros. A sua mola propulsora continua sendo a mesma da escravidão antiga, que é o lucro e a acumulação de riqueza. ${ }^{24}$

23 WANDELLI, Leonardo Vieira. O direito humano e fundamental ao trabalho. Fundamentação e exigibilidade. São Paulo: LTr, 2012. p. 141.

24 FÁVERO FILHO, Nicanor. Trabalho escravo: vilipendio à dignidade humana. In: PIOVESAN, Flavia; CARVALHO, Luciana Paula Vaz de (Org.). Direitos humanos e direito do trabalho. São Paulo: Atlas, 2010. p. 270. 
A legislação brasileira é bastante ampla no sentido de erradicação do trabalho escravo. Em 23.12.2002 foi publicada a Lei no 10.608, inserindo regras referentes ao trabalho forçado ou reduzido à condição análoga à de escravo na legislação que instituiu o seguro-desemprego (Lei no 7.998/1990). De acordo com aquela legislação, todo e qualquer trabalhador resgatado de tal situação terá direito ao recebimento de 3 (três) parcelas de um salário mínimo. Mais importante que o simples pagamento das três parcelas, é a previsão legal de encaminhamento do trabalhador resgatado, pelo Ministério do Trabalho, para qualificação profissional e recolocação no mercado de trabalho, por meio do Sistema Nacional de Emprego Sine, na forma a ser estabelecida pelo Conselho Deliberativo do Fundo de Amparo ao Trabalhador - Codefat.

Em março de 2003, foi lançado o Plano Nacional de Erradicação do Trabalho Escravo, com 75 (setenta e cinco) ações do Governo Federal.

Em dezembro do mesmo ano, foi publicada a Lei $n-10.803$, modificando o art. 149 do Código Penal brasileiro e igualando o trabalho degradante ao trabalho escravo, com pena de reclusão de 2 (dois) a 8 (oito) anos e multa, além de agravante caso o crime seja cometido contra criança ou adolescente ou por preconceito.

No dia 12.5.2004, véspera de aniversário da Lei Áurea, foi aprovada pelo Governo Federal, na Comissão Especial da Câmara, a Proposta de Emenda Constitucional (PEC) № 438/2001, versando sobre o confisco de terras onde fosse encontrado trabalho escravo ou análogo à escravidão. A bancada ruralista, porém, apresentou duas emendas à proposta, sobre a garantia de que a expropriação só ocorreria depois de esgotado o processo jurídico e sobre a equiparação do trabalho rural com o urbano. No dia 22.5.2012, no Plenário do Pleno da Câmara dos Deputados Federais, foi aprovada, em segundo turno, tendo 360 votos a favor, 29 votos contra e 25 abstenções, em um total de 414 deputados presentes na sessão, com discussão do Deputado Nelson Marquezelli, do Partido Trabalhista Brasileiro (PTB), de São Paulo.

Ao invés da PEC supracitada, foi publicada no dia 6.8.2015 a Instrução Normativa no 83, do Instituto Nacional de Colonização e Reforma Agrária (Incra), que logo em seguida foi suspensa pela Advocacia Geral da União, justamente por não existir norma neste sentido e da gravidade do ato de confisco de terras.

Também em 2006 foi aprovada a Política Nacional de Enfrentamento do Tráfico de Pessoas, por meio do Decreto no 5.948. Em 2007 foi realizado o primeiro seminário nacional sobre o tema do enfrentamento do tráfico de pessoas. Já em 2008, o Plano Nacional de Enfrentamento ao Tráfico de Pessoas foi aprovado por meio do Decreto no 6.347. Suas metas e ações foram pensadas sobre três focos: prevenção, repressão, responsabilização e atenção às vítimas. 
Interessante frisar que em uma situação de cárcere privado por dívida, já comentada na apresentação deste trabalho, entendemos que a casa de prostituição (e/ou o hotel ligado ao mesmo proprietário) também poderia ser fruto de confisco, com venda destes bens para pagar não somente os problemas materiais do confinamento irregular dos seres humanos aliciados, mas também e principalmente um acompanhamento psicológico digno para a pessoa que sofreu o dano.

Convém explicar que o instituto da desapropriação não se confunde com a expropriação, sendo que, na primeira, não ocorre privação da propriedade nem mesmo diminuição do direito de propriedade, como se evidencia na expropriação, que tem sentido mais amplo e pode significar a perda ou a diminuição patrimonial. $\mathrm{Na}$ desapropriação, registra-se, apenas, uma conversão da propriedade, consequente da venda forçada por interesse de ordem pública. Não ocorre, pois, qualquer ofensa a seu patrimônio, em consequência, não se afetando o direito de propriedade em pessoa. ${ }^{25}$

A expropriação encontrada na proposta de emenda constitucional supracitada acarretará um confisco do imóvel, juntamente com todos os bens de valores econômicos apreendidos em decorrência da exploração, respeitados os preceitos constitucionais do contraditório e da ampla defesa. A alteração da Constituição visa a proteger o exercício das liberdades individuais, assim como o atendimento ao princípio fundante da ordem econômica e financeira e da propriedade privada: a função social da propriedade. Notamos que, no direito pós-moderno, a propriedade existe e continua existindo, mas agora, também, com condicionantes sociais. ${ }^{26}$

Sobre este mesmo tema, encontramos alguns conceitos na Convenção de Palermo, aprovada pelo Brasil no Decreto no 5.015/2004:27

\section{Artigo 2 Terminologia}

Para efeitos da presente Convenção, entende-se por:

a) "Grupo criminoso organizado" - grupo estruturado de três ou mais pessoas, existente há algum tempo e atuando concertadamente com o propósito de cometer uma ou mais infrações graves ou enunciadas na presente Convenção, com a intenção de obter, direta ou indiretamente, um benefício econômico ou outro benefício material; [...]

25 SILVA, De Plácido e. Vocabulário jurídico. 18. ed. Rio de Janeiro: Forense, 2001. p. 256.

26 BRASIL. Presidência da República. Decreto no 5.015/2004. Promulga o Protocolo Contra Contrabando de Migrantes por Terra, Mar e Ar, Complemento à Convenção das Nações Unidas Contra o Crime Organizado Transnacional. Disponivel em: <http://www.planalto.gov.br/ccivil_03/_Ato2004-2006/2004/Decreto/ D5016.htm>. Acesso em: 30 ago. 2017.

27 FRANCO SOBRINHO, Manoel de Oliveira. Desapropriação. 2. ed. São Paulo: Saraiva, 1996. p. 397. 
d) "Bens" - os ativos de qualquer tipo, corpóreos ou incorpóreos, móveis ou imóveis, tangíveis ou intangiveis, e os documentos ou instrumentos jurídicos que atestem a propriedade ou outros direitos sobre os referidos ativos; e) "Produto do crime" - os bens de qualquer tipo, provenientes, direta ou indiretamente, da prática de um crime; f) "Bloqueio" ou "apreensão" - a proibição temporária de transferir, converter, dispor ou movimentar bens, ou a custódia ou controle temporário de bens, por decisão de um tribunal ou de outra autoridade competente; g) "Confisco" - a privação com caráter definitivo de bens, por decisão de um tribunal ou outra autoridade competente;

Segundo o Protocolo de Palermo (2000), o tráfico de pessoas é caracterizado por:

[...] recrutamento, o transporte, a transferência, o alojamento ou o acolhimento de pessoas, recorrendo à ameaça ou uso da força ou a outras formas de coação, ao rapto, à fraude, ao engano, ao abuso de autoridade ou à situação de vulnerabilidade ou à entrega ou aceitação de pagamentos ou benefícios para obter o consentimento de uma pessoa que tenha autoridade sobre outra para fins de exploração. A exploração incluirá, no mínimo, a exploração da prostituição de outrem ou outras formas de exploração sexual, o trabalho ou serviços forçados, escravatura ou práticas similares à escravatura, a servidão ou a remoção de órgãos. (Protocolo Adicional à Convenção das Nações Unidas contra o Crime Organizado Transnacional, ratificado pelo Brasil em 2004). O Diretor Executivo da UNODC reconhece que "a expressão 'tráfico de pessoas' pode gerar confusão, pois enfatiza os aspectos comerciais de um crime que seria mais exato qualificar de “escravidão'”. ${ }^{28}$

Já o Decreto no 5.016/2004 ${ }^{29}$ trouxe a aplicação do Protocolo contra Contrabando de Migrantes por Terra, Mar e Ar, Complemento à Convenção das Nações Unidas Contra o Crime Organizado Transnacional.

Importante frisar o trabalho do Ministério do Trabalho, por meio do Grupo Especial de Fiscalização Móvel, criado em 14.6.1995 pelo Grupo Executivo para a

28 UNODC. UN.GIFT 2009. Disponível em: <http://www.unodc.org/documents/human-trafficking/TIP_ Executive_summaries.pdf $>$. Acesso em: 30 ago. 2017.

29 BRASIL. Presidência da República. Decreto n 5.015/2004. Promulga o Protocolo Contra Contrabando de Migrantes por Terra, Mar e Ar, Complemento à Convenção das Nações Unidas Contra o Crime Organizado Transnacional. Disponível em: <http://www.planalto.gov.br/ccivil_03/_Ato2004-2006/2004/Decreto/ D5016.htm>. Acesso em: 30 ago. 2017. 
Repressão do Trabalho Forçado (Gertraf), que, mesmo com todas as dificuldades existentes nesse tipo de situação, tem resgatado milhares de pessoas por ano, com o auxílio da Polícia Federal.

Além das unidades que trabalham com a prevenção e acompanhamento de casos, em 16.3.2011 foi criada a Comissão Parlamentar de Inquérito (CPI), para investigar casos da máfia do tráfico de pessoas. Até agora, foram realizadas 27 reuniões e quatro diligências. Atualmente, mais de 30 pessoas, entre homens e mulheres, cumprem pena no Brasil devido ao crime de tráfico de pessoas, segundo o Ministério da Justiça. ${ }^{30}$

No Senado Federal brasileiro, da mesma forma, houve grande movimentação, inclusive com a criação da Comissão Parlamentar de Inquérito que investiga o tráfico nacional e internacional de pessoas no Brasil, concluindo, em sessão ocorrida na metade de 2012, pela apresentação de um projeto de lei que procura adequar a valoração dada pela legislação penal brasileira ao crime de tráfico de pessoas aos termos da Convenção de Palermo, das Nações Unidas, contra o crime organizado transnacional, ratificado pelo Brasil em 2003. De acordo com o relatório, uma das falhas da legislação vigente é vincular o tráfico de pessoas exclusivamente à exploração sexual, deixando de lado, por exemplo, os casos ligados à remoção de órgãos ou ao trabalho escravo. ${ }^{31}$

No projeto, a prática do tráfico de pessoas é definida como:

[...] agenciar, aliciar, recrutar, transportar, transferir, alojar ou acolher pessoa, mediante grave ameaça, violência, coação, fraude ou abuso, com a finalidade de explorar alguém para: remoção de órgãos tecidos ou partes do corpo; trabalho em condições análogas à de escravo; servidão por dívida; casamento servil; adoção ilegal; exploração sexual; qualquer forma que acarrete ofensa relevante à dignidade da pessoa ou a sua integridade física. ${ }^{32}$

A pena prevista é de prisão, de quatro a dez anos, e multa. De acordo com Lídice da Mata, a pena se harmoniza com outros tipos penais de gravidade

30 SEIXAS, Kleyzer. Tráfico de pessoas é maior entre mulheres e crianças. A Tarde, 13 nov. 2012. Disponível em: <http://atarde.uol.com.br/bahia/materias/1466971-trafico-de-pessoas-e-maior-entre-mulheres-e-criancas>. Acesso em: 29 jan. 2013.

31 ABREU, Raíssa. CPI do tráfico de pessoas aprova relatório final com proposta de mudança na lei penal. Senado Notícias, 19 dez. 2012. Disponível em: <http://www12.senado.gov.br/noticias/ materias/2012/12/19/cpi-do-trafico-de-pessoas-aprova-relatorio-final>. Acesso em: 30 ago. 2017.

32 CPI - Tráfico nacional e internacional de pessoas no Brasil - CPITRAFPE. Senado Federal. Disponível em: <http://www.senado.gov.br/atividade/Comissoes/comissao.asp?origem=\&com=1551>. Acesso em: 30 ago. 2017. 
equivalente, como o tráfico de drogas e de armas. Ela também apontou que, pelo projeto, o tráfico de pessoas deixa de ser caracterizado como crime contra a dignidade sexual para ser considerado crime contra a dignidade da pessoa. ${ }^{33}$

Com relação à acima referida CPI, convém salientar:

[...] também aprovou a apresentação de um projeto de resolução que dispõe sobre a realização de audiências públicas periódicas com o Ministro da Justiça, para prestar esclarecimentos perante a Comissão de Direitos Humanos e Legislação Participativa (CDH) sobre diretrizes e implementação da política sobre o tráfico de pessoas. ${ }^{34}$

A Câmara dos Deputados Federais criou, em 9.2.2012, uma Comissão Parlamentar de Inquérito para investigar a exploração do trabalho escravo ou análogo ao de escravo, em atividades rurais e urbanas, de todo o território nacional.

Sobre a supracitada comissão é importante destacar o seguinte:

Em razão da complexidade do seu objeto, que exigiu a criação de diversas frentes de atuação, tendo em vista a necessidade de efetivação de diversas diligências e outros atos processuais e frisando a relevância do mapeamento da exploração do trabalho escravo a Comissão solicitou a prorrogação do seu prazo de funcionamento, nos termos do §3ำ do art. 35 do Regimento Interno da Câmara dos Deputados, combinado com o $2^{\circ}{ }^{\circ}$ do art. 5으 da Lei $\mathrm{n}^{\circ} 1.579$, de 18 de março de 1952, por sessenta dias, a partir de 10 de agosto de 2012, o que foi aprovado pelo Plenário da Câmara dos Deputados em 03 de julho de $2012 .^{35}$

A Lei no 11.948, de 16.6.2009, em seu art. 4ํ, vedou a concessão ou a renovação de quaisquer empréstimos ou financiamentos pelo Banco Nacional de Desenvolvimento Econômico e Social (BNDES) “a empresas da iniciativa privada

33 ABREU, Raíssa. CPI do tráfico de pessoas aprova relatório final com proposta de mudança na lei penal. Senado Notícias, 19 dez. 2012. Disponível em: <http://www12.senado.gov.br/noticias/ materias/2012/12/19/cpi-do-trafico-de-pessoas-aprova-relatorio-final>. Acesso em: 30 ago. 2017.

34 ABREU, Raíssa. CPI do tráfico de pessoas aprova relatório final com proposta de mudança na lei penal. Senado Notícias, 19 dez. 2012. Disponível em: <http://www12.senado.gov.br/noticias/ materias/2012/12/19/cpi-do-trafico-de-pessoas-aprova-relatorio-final>. Acesso em: 30 ago. 2017.

35 CÂMARA DOS DEPUTADOS. Comissão Parlamentar de Inquérito. Trabalho escravo - CPITRAES. Disponível em: <//www2.camara.leg.br/atividade-legislativa/comissoes/comissoes-temporarias/parlamentar-deinquerito/54a-legislatura/cpi-trabalho-escravo/conheca-a-comissao/apresentação>. Acesso em: 30 ago. 2017. 
cujos dirigentes sejam condenados por assédio moral ou sexual, racismo, trabalho infantil, trabalho escravo ou crime contra o meio ambiente". ${ }^{36}$

O Ministério do Trabalho, com a Secretaria de Direitos Humanos, em 12.5.2011, firmou a Portaria Interministerial MTE/SEDH № 2,37 estabelecendo regras sobre o cadastro de empregadores que tenham submetido trabalhadores a condições análogas à de escravo, revogando a Portaria MTE no 540/2004.

O mesmo Ministério do Trabalho, com a Secretaria de Inspeção do Trabalho, pela Portaria no 447, de 19.9.2014, ${ }^{38} 39$ instituiu o Grupo Especial de Fiscalização Móvel de Combate ao Trabalho em Condições Análogas às de Escravo (GEFM).

Ainda, a Resolução Normativa ํำ122, de 3.8.2016, dispõe sobre a concessão de permanência no Brasil a estrangeiro considerado vítima de tráfico de pessoas e/ou de trabalho análogo ao de escravo. ${ }^{40}$

No site encontrado, nesta nota de rodapé, apresenta-se o Quadro das Operações de Fiscalização para Erradicação do Trabalho Escravo - SIT/SRTE 2016 - atualizado até 13.3.2017. ${ }^{41}$

O Conselho Nacional de Justiça fez um levantamento nos Tribunais Regionais Federais trazendo a seguinte conclusão:

Levantamento feito a pedido do Conselho Nacional de Justiça (CNJ) junto aos Tribunais Regionais Federais (TRFs) revelou que, de 2005 a 2012, o número de processos judiciais no Brasil envolvendo o crime de tráfico de pessoas e o crime de redução à condição análoga à de escravo chegou a 1.163. Desses, seguem em tramitação 428. 0 levantamento contribuiu para subsidiar o primeiro relatório sobre o Tráfico de Pessoas no Brasil elaborado pela Secretaria Nacional de Justiça do Ministério da Justiça (SNJ/MJ) em parceria com o Escritório das Nações Unidas sobre Drogas e Crime (UNODC), que revelou a existência de 475 vítimas do tráfico no Brasil entre 2005 e $2011 .{ }^{42}$

36 BRASIL. Lei no 11.948, de 16 de junho de 2009. Disponível em: <http://www.planalto.gov.br/ccivil_03/_ ato2007-2010/2009/lei/l11948.htm>. Acesso em: 30 ago. 2017. Grifos nossos.

37 BRASIL. Portaria Interministerial MTE/SEDH no 02, de 12 de maio de 2011. Disponível em: <http://www. normaslegais.com.br/legislacao/portariainter_mtesedh02_2011.htm>. Acesso em: 30 ago. 2017.

38 DOU de 22 set. 2014 - Seção 1, retificada no DOU de 23 set. 2014 - Seção 1.

39 BRASIL. Portaria no 447, de 19 de setembro de 2014. Disponível em: <file:///Users/VILLATORE/ Downloads/0447_Portaria_n._447_Institui_o_GEFM_-_Trabalho_Escravo.pdf>. Acesso em: 30 ago. 2017.

40 BRASIL. Resolução Normativa no 122, de 03 ago. 2016. Disponível em: <file:///Users/VILLATORE/ Downloads/Quadro_Resumo_2016por_UF_para_internet.pdf >. Acesso em: 30 ago. 2017.

41 BRASIL. Quadro das operações de fiscalização para erradicação do trabalho escravo - SIT/SRTE. 2016. Disponível em: <file:///Users/VILLATORE/Downloads/2694_RN-122.pdf>. Acesso em: 30 ago. 2017.

42 LEVANTAMENTO do CNJ revela 428 processos por tráfico de pessoas e trabalho escravo no País. Jusbrasil, 2013. Disponível em: <https://correio-forense.jusbrasil.com.br/noticias/213310004/levantamento-docnj-revela-428-processos-por-trafico-de-pessoas-e-trabalho-escravo-no-pais>. Acesso em: 30 ago. 2017. 
Neste aspecto há uma série de possibilidades de tipificação de crime:

Os processos contabilizados dizem respeito especificamente aos crimes de tráfico internacional de pessoas para fim de exploração sexual (Código Penal, art. 231); tráfico internacional de pessoas (CP, 231); tráfico interno de pessoa para fim de exploração sexual ( $C P$, art. $231 \mathrm{~A})$; tráfico interno de pessoas (CP, art. $231 \mathrm{~A})$; redução a condição análoga à de escravo (CP, art. 149); crimes previstos no estatuto da criança e adolescente (ECA, art. 239); e crimes de Lei de Remoção de Órgãos e Tecidos (Lei 9.434). Os dados foram coletados dos TRFs, uma vez que tais crimes são de competência da Justiça Federal. ${ }^{43}$

Complementando a legislação supracitada, surgiu, em 6.10.2016, a Lei no 13.344, que dispõe sobre prevenção e repressão ao tráfico interno e internacional de pessoas e sobre medidas de atenção às vítimas:

Tráfico de Pessoas

Art. 149-A. Agenciar, aliciar, recrutar, transportar, transferir, comprar, alojar ou acolher pessoa, mediante grave ameaça, violência, coação, fraude ou abuso, com a finalidade de:

I - remover-lhe órgãos, tecidos ou partes do corpo;

II - submetê-la a trabalho em condições análogas à de escravo;

III - submetê-la a qualquer tipo de servidão;

IV - adoção ilegal; ou

V - exploração sexual.

Pena - reclusão, de 4 (quatro) a 8 (oito) anos, e multa.

§1ํ A pena é aumentada de um terço até a metade se:

I - o crime for cometido por funcionário público no exercício de suas funções ou a pretexto de exercê-las;

II - o crime for cometido contra criança, adolescente ou pessoa idosa ou com deficiência;

III - o agente se prevalecer de relações de parentesco, domésticas, de coabitação, de hospitalidade, de dependência econômica, de autoridade ou de superioridade hierárquica inerente ao exercício de emprego, cargo ou função; ou

43 LEVANTAMENTO do CNJ revela 428 processos por tráfico de pessoas e trabalho escravo no País. Jusbrasil, 2013. Disponivel em: <https://correio-forense.jusbrasil.com.br/noticias/213310004/levantamento-docnj-revela-428-processos-por-trafico-de-pessoas-e-trabalho-escravo-no-pais>. Acesso em: 30 ago. 2017. Grifos nossos. 
IV - a vítima do tráfico de pessoas for retirada do território nacional.

§2ำ A pena é reduzida de um a dois terços se o agente for primário e não integrar organização criminosa. ${ }^{44}$

Em 16.10.2017 o Ministério do Trabalho publicou, no Diário Oficial da União, a Portaria $\mathrm{n}$-1.129, indicando avanços, da seguinte forma:

aprimora e dá segurança jurídica à atuação do Estado Brasileiro, ao dispor sobre os conceitos de trabalho forçado, jornada exaustiva e condições análogas à de escravo, para fins de concessão de segurodesemprego ao trabalhador que vier a ser resgatado em fiscalização promovida por auditores fiscais do trabalho, bem como para inclusão do nome de empregadores no Cadastro de Empregadores que tenham submetido trabalhadores à condição análoga à de escravo, estabelecido pela PI MTPS/MMIRDH no 4, de 15.05.2016. Entre as principais medidas decorrentes da portaria estão as seguintes: a partir de agora, uma investigação criminal será aberta de forma simultânea à emissão do auto de infração; a Polícia Federal estará inserida nas ações; e as multas terão aumentos que, em alguns casos, chegarão a $500 \% .{ }^{45}$

A supracitada portaria foi suspensa, por liminar deferida pela Ministra Rosa Weber, do Supremo Tribunal Federal (STF), pelos seguintes questionamentos:

Arguição de Descumprimento de Preceito Fundamental (ADPF) 489, ajuizada pelo partido Rede Sustentabilidade. Tramita ainda no STF ação semelhante (ADPF 491) ajuizada pela Confederação Nacional das Profissões Liberais (CNPL), também sob relatoria da ministra Rosa Weber.

Em sua decisão na ação proposta pela Rede, a ministra considera cabível a ADPF, observando que a definição conceitual proposta na portaria ministerial "afeta as ações e políticas públicas do Estado brasileiro, no tocante ao combate ao trabalho escravo, em três dimensões: repressiva (ao repercutir nas fiscalizações procedidas pelo Ministério do Trabalho), pedagógico-preventiva (ao disciplinar a inclusão de nomes no Cadastro de Empregadores que tenham submetido

44 BRASIL. Lei no 13.344, de 06 de outubro de 2016. Disponível em: <http://www.planalto.gov.br/ ccivil_03/_ato2015-2018/2016/lei/L13344.htm>. Acesso em: 30 ago. 2017. Grifos nossos.

45 MINISTÉRIO DO TRABALHO. Nota oficial sobre a Portaria no 1.129/2017. Disponível em: <http://trabalho. gov.br/noticias/5122-nota-oficial-sobre-portaria-n-1-129-2017>. Acesso em: 31 out. 2017. 
trabalhadores à condição análoga à de escravo) e reparativa (concessão de seguro-desemprego ao trabalhador resgatado)". ${ }^{46}$

Uma dificuldade para a condenação de quem pratica estes atos absurdos ocorre porque:

\begin{abstract}
Sem as testemunhas, torna-se muito mais dificil transformar as denúncias em provas que sirvam à condenação dos responsáveis pelo trabalho escravo. Uma articulação mais precisa entre as instituições que participam desses chamados "grupos móveis" - Ministério do Trabalho, Ministério Público do Trabalho (MPT), Polícia Federal (PF), Defensoria Pública da União (DPU), Polícia Rodoviária Federal (PRF), além da PGR - e o Judiciário, responsável por emitir mandados de busca e apreensão, ampliaria o número de pessoas libertadas em operações de resgate. Entre 1995 e 2015, foram resgatados cerca de 50 mil trabalhadores em 1.785 ações de fiscalização desses grupos, de acordo com o governo Federal. ${ }^{47}$
\end{abstract}

Na jurisprudência, analisamos três decisões recentes de tribunais nacionais: o Tribunal Regional do Trabalho da 4a Região, o Tribunal Superior do Trabalho e o Supremo Tribunal Federal, para entender como são julgados, nestas instâncias, pedidos referentes ao trabalho forçado.

O Tribunal Regional do Trabalho da 4a Região - RS já decidiu aplicando indenização de dano moral por desrespeito ao contrato, não caracterizando a situação análoga à escravidão, no seguinte sentido:

AÇÃO CIVIL PÚBLICA. MEIO AMBIENTE DO TRABALHO. VIOLAÇÃO A DIREITOS FUNDAMENTAIS. TUTELA INIBITÓRIA COLETIVA. A tutela inibitória coletiva é, por excelência, o instrumento adequado à proteção de um meio ambiente do trabalho hígido. Constatada a lesão ao direito fundamental em foco, impõe-se o estabelecimento de obrigações de fazer e de não fazer, sob pena de multa (astreites), como modo de impedir a ocorrência de novos ilícitos, sem prejuízo do ressarcimento dos danos morais coletivos. (TRT4 - RS, 1른

46 MINISTRA Rosa Weber suspende efeitos de portaria ministerial sobre trabalho escravo. Notícias STF, 24 out. 2017. Disponível em: <www.stf.jus.br/portal/cms/verNoticiaDetalhe.asp?idConteudo=359907>. Acesso em: 31 out. 2017.

47 TRF4 - Justiça busca maior integração entre órgãos de combate ao trabalho escravo. Diário Indústria \& Comércio, 13 mar. 2017. Disponível em: <http://www.diarioinduscom.com/trt4-justica-busca-maiorintegracao-entre-orgaos-de-combate-ao-trabalho-escravo/>. Acesso em: 30 ago. 2017. 
Acórdão - Processo no 0021076-41.2014.5.04.0006. Redator Magistrado Fabiano Holz Beserra, 17.2.2017)

No supracitado caso, uma construtora de grande porte nacional e internacional foi acionada (ação civil pública) pelo Ministério Público do Trabalho da 4aㅡ Região porque descumpriu sua ordem de interdição após notar risco de acidente de trabalho com possibilidade de morte de vários empregados em uma obra.

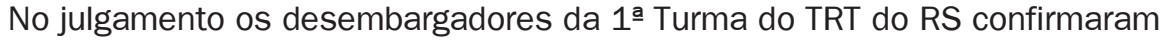
a alegação do Ministério Público do RS de que a própria empresa afirmou o descumprimento desta ordem, tendo, inclusive, não contestado os autos de infração originários do Ministério do Trabalho.

Além de possível multa diária de milhares de reais (200 mil e 15 mil reais) dependendo do ato praticado ou que se deixar de realizar apesar de determinação judicial, houve a determinação de pagamento de multa de 1 milhão de reais por dano moral coletivo, inclusive citando no acórdão trecho doutrinário ligando tal fato ocorrido a uma verdadeira situação análoga à escravidão no seguinte sentido:

[...] arbitro a indenização em $\mathrm{R} \$ 1.000 .000,00$ (um milhão de reais limites da inicial - pedido "b"), a ser revertida ao Fundo de Defesa de Direitos Difusos. (destaque no original)

[...] Com efeito, Xisto Tiago de Medeiros Neto, em obra de inestimável valor sobre o dano moral coletivo, afirma que "em sede trabalhista, colhem-se, primeiramente, os exemplos ofertados por João Carlos Teixeira, que aponta para configuração de danos morais coletivos as hipóteses de lesão ao meio ambiente do trabalho, decorrente da violação das normas de proteção à saúde e à segurança dos trabalhadores; submissão dos trabalhadores à condição análoga à de escravo, com privação dos direitos básicos inerentes à dignidade da pessoa humana; e exploração de trabalho de criança ou de adolescente". (Dano Moral Múltiplos Aspectos nas Relações de trabalho. 2ª. ed. LTr - São Paulo, Junho 2006. Pág. 308-10).

Muito comum, portanto, o desrespeito de empresas ligadas à construção civil, ainda mais em uma obra com significativa urgência, como ocorreu neste caso em concreto.

Em um caso de risco menor, mas não menos importante, o Tribunal Superior do Trabalho decidiu:

RECURSO DE REVISTA - PROCESSO SOB A VIGÊNCIA DA LEI № 13.015/2014, DO CPC/2015 E DA INSTRUÇÃO NORMATIVA № 40 
DO TST - TRABALHADOR RURAL - INSTALAÇÕES SANITÁRIAS - CONDIÇÕES PRECÁRIAS - DESCUMPRIMENTO DAS REGRAS MÍNIMAS DE HIGIENE - LESÃO AO PRINCÍPIO DA DIGNIDADE HUMANA - DANO MORAL - PRESENÇA DOS PRESSUPOSTOS DA RESPONSABILIDADE CIVIL DO EMPREGADOR - INDENIZAÇÃO. 1. Ao deixar de atender às condições sanitárias mínimas exigidas pela Norma Regulamentar no 31 do Ministério do Trabalho e Emprego, proporcionando verdadeira degradação dos trabalhadores de cuja força de trabalho se beneficia, a reclamada, com seu comportamento negligente, efetivamente ofende a honra e a integridade física do autor, dando ensejo à condenação ao pagamento de danos morais. O caráter rústico do trabalho agrícola em nada justifica o descumprimento de condições sanitárias básicas, uma vez que a própria normatização do Ministério do Trabalho e Emprego considera as condições peculiares de cada ambiente de trabaIho e autoriza que, no caso de frentes de trabalho, que se instalam em cada local de colheita de forma provisória, o empregador lance mão de aparelhos sanitários móveis e de pouca complexidade na sua instalação. Portanto, porque amparada na ordem jurídica constitucional que afirma a centralidade da pessoa humana e dos seus direitos fundamentais, a decisão regional não comporta reparos. 2. Para possibilitar a revisão do valor atribuído aos danos morais, a parte recorrente deve apontar, explicitar e demonstrar inequivocamente, em seu recurso de revista, o desequilíbrio entre o valor da indenização e o dano extrapatrimonial causado ao empregado, considerando os critérios adotados pelo Tribunal Regional, o que não restou evidenciado. A parte limitou-se a indicar genericamente os critérios a serem observados para a fixação do valor indenizatório, sem demonstrar circunstâncias fáticas nos autos que justificariam a pretendida redução do quantum indenizatório. Recurso de revista não conhecido. (TST, 7a. Turma. RR no 10751-32.2016.5.03.0081. Rel. Min. Luiz Philippe Vieira de Mello Filho, j. 30.8.2017. DEJT, 1ํset. 2017)

Como verificado no caso em concreto supracitado, o problema ocorria pelo descumprimento pelo empregador rural de regras de saúde e de segurança do trabalhador, mais precisamente neste caso por condições precárias de higiene, com níveis abaixo do mínimo nas instalações sanitárias, em desrespeito à Norma Regulamentadora ํo 31 do Ministério do Trabalho.

Pode-se, em um primeiro momento, afirmar que a questão do TRT do RS é mais caracterizadora de uma situação análoga à escravidão, pois se remete ao risco de um ou mais trabalhadores perderem sua vida em um acidente que não ocorreria se houvesse a utilização correta de equipamentos individuais e 
coletivos de proteção dos empregados, mas no segundo caso analisado, no TST, há uma tendência mais fácil de caracterização, pois se remete ao trabalho rural, de mais difícil fiscalização, em que é comum a precarização do trabalho e das condições mínimas de higiene, sanitárias, mas também de saúde e de segurança do trabalhador.

Importante recordar que a escravidão com restrição de ir e vir (locomoção) está cada vez mais difícil de se verificar, mas esta situação análoga à escravidão parece multiplicar em nossa sociedade, infelizmente.

O nosso Tribunal maior nacional brasileiro decidiu desta forma:

PROCESSUAL PENAL. HABEAS CORPUS CONTRA ATO DE MINISTRO DO STF. REDUÇÃO A CONDIÇÃO ANÁLOGA À DE ESCRAVO. TRANCAMENTO DA AÇÃO PENAL. INADEQUAÇÃO DA VIA ELEITA. 1. A jurisprudência atual e majoritária do Plenário do Supremo Tribunal Federal não admite a impetração de habeas corpus contra ato de Ministro do STF. 2. O trancamento da ação penal, pela via restrita do habeas corpus, só é possível quando estiverem demonstradas a atipicidade da conduta, a extinção da punibilidade ou a evidente ausência de justa causa. Precedentes. 3. Hipótese em que inexiste a comprovação de risco irreparável ao paciente, que bem poderá articular toda a matéria de defesa no momento processual adequado. 4. Habeas Corpus não conhecido, por inadequação da via eleita. 1. Trata-se de habeas corpus, impetrado em favor do Deputado Federal Paulo Roberto Gomes Mansur, tendo como autoridade apontada como coatora o Ministro Relator da Ação Penal no 635/GO, em tramitação neste Supremo Tribunal Federal. 2. Extrai-se dos autos que o paciente e outros três acusados foram denunciados perante o Juízo da Comarca de Porangatu/GO pelo crime de redução a condição análoga à de escravo, na forma dos artigos 149, caput, e §2으. I, c/c os artigos 62 , I, e 71, todos do Código Penal. 3. Após o recebimento da denúncia, o paciente foi diplomado no cargo de Deputado Federal, o que deu ensejo à remessa dos autos para este Supremo Tribunal Federal. O Relator do Inq. 2.496, Ministro Celso de Mello, determinou o desmembramento da causa "com relação aos denunciados que não possuem prerrogativa de função". Na sequência, determinou a reautuação do feito como ação penal. 4. Neste habeas corpus, a parte impetrante afirma que 0 Juízo da Comarca de Porangatu/GO, ao receber os autos após o desmembramento do processo, declinou da competência para o Juízo da Comarca de São Miguel do Araguaia/Go. Juízo, esse, contudo, que entendeu caracterizada hipótese de crime da competência da Justiça Federal. 5. Prossegue a defesa para informar que, encaminhado o 
processo dos corréus para o Juízo da Subseção Judiciária de Uruaçu/ GO, deu-se a desclassificação da conduta para o tipo descrito no art. 203 do CP (Frustração de direito assegurado por lei trabalhista). O que motivou o retorno dos autos para o Juízo da Comarca de São Miguel do Araguaia/GO, local dos fatos, que declarou extinta a punibilidade pela ocorrência da prescrição. 6 . Nessas condições, a parte impetrante sustenta a ausência de justa causa para a propositura da ação penal, sob o argumento de que a denúncia "NÃO DESCREVEU AS CIRCUNSTÂNCIAS RELATIVAS À DURAÇÃO DA EXPOSIÇÃO DOS TRABALHADORES ÀS CONDIÇÕES DEGRADANTES DE TRABALHO, ENTRE OUTRAS IRREGULARIDADES DECORRENTES A CARACTERIZAR TRABALHO ANÁLOGO À DE ESCRAVO, dificultando o exercício de defesa e nulificando a peça proemial pública". Destaca, ainda, a ausência de indícios da autoria delitiva. Daí o pedido de concessão da ordem de habeas corpus a fim de determinar o trancamento da AP 635/GO. Decido. 6. O habeas corpus não deve ser conhecido. 7. O Supremo Tribunal Federal consolidou orientação no sentido do descabimento da impetração de habeas corpus contra ato de Ministro, Turma ou do Plenário do Tribunal (Cf. Súmula 606/STF; HC 100.738, Redatora para o acórdão a Mina . Cármen Lúcia; HC 101.432, Redator para o acórdão o Min. Dias Toffoli; HC 88.247-AgR-AgR, Rel. Min. Celso de Mello; HC 91.020-AgR, Rel. Min. Celso de Mello; HC 86.548, Rel. Min. Cezar Peluso). 8. Muito embora essa orientação jurisprudencial tenha sido rediscutida no julgamento do HC 127.483, Rel. Min. Dias Toffoli (oportunidade em que se verificou o empate na votação), o Plenário do Supremo Tribunal Federal, em 17.02.2016, "reafirmou sua jurisprudência no sentido de não ser cabível "habeas corpus" impetrado contra decisão monocrática de ministro da Corte." (Informativo no 814 do STF). Refiro-me ao HC 105.959, Redator para o acórdão o Ministro Edson Fachin, julgado com a participação de todos os integrantes do Tribunal. De modo que o processo deve ser extinto sem resolução do mérito, por inadequação da via eleita. 9. Ainda que não fosse o caso de descabimento da impetração, é pacífica a orientação jurisprudencial do Supremo Tribunal Federal, no sentido de que o trancamento de ação penal só é possível quando estiverem comprovadas, de logo, a atipicidade da conduta, a extinção da punibilidade ou a evidente ausência de justa causa (v.g HC 103.891, Redator para o acórdão o Min. Ricardo Lewandowski; HC 86.656, Rel. Min. Ayres Britto; HC 81.648, Rel. Min.Ilmar Galvão; HC 118.066-AgR, Rel. ${ }^{\text {a }}$ Min. a Rosa Weber, e HC 104.267, Rel. Min. Luiz Fux). E as peças contidas nos autos não evidenciam nenhuma teratologia, ilegalidade flagrante ou abuso de poder que autorize o encerramento prematuro 
do processo-crime. Demais disso, não encontro nenhum risco de prejuízo irreparável ao paciente, que bem poderá articular toda a matéria de defesa no momento processual oportuno. 10. Diante do exposto, com base no art. 21, $\S 1^{\circ}$, do RI/STF, não conheço do habeas corpus. Publique-se. Brasília, 23 de agosto de 2016. Ministro Luís Roberto Barroso Relator Documento assinado digitalmente. (HC № 135.221. Rel. Min. Roberto Barroso, j. 23.8.2016. DJe-181, divulg. 25.8.2016, public. 26.8.2016)

No julgamento do habeas corpus no Supremo Tribunal Federal, restou claro que no entendimento dos ministros não havia razão para deferimento do pedido, pois mesmo com a alegação de que não havia limitação do pedido com relação ao período da situação análoga à escravidão, ele nenhum risco de prejuízo irreparável corria, podendo alegar tudo em sua defesa. Neste caso, matéria tipicamente penal.

Notamos que a caracterização de trabalho forçado é difícil, muitas vezes sendo enquadrado como assédio moral, com uma indenização menor e também sem os direitos naquele sentido, como os previstos no art. 2ํ-C da Lei no $7.998 / 1990$.

Além da tipificação encontrada nos arts. 149 e 149-A do Código Penal, outras caracterizações possíveis e aplicáveis são de assédio sexual, do art. 216-A.

Outros possíveis crimes também encontrados no Código Penal são aqueles elencados nos arts. 197 a 207, também conhecidos como crimes contra a organização do trabalho, mas que poucas práticas possuem, sendo que a maioria está ligada a movimentos coletivos.

Os dois últimos mais nos importam porque o art. 206 está ligado a aliciamento para o fim de emigração:

Art. 206. Recrutar trabalhadores, mediante fraude, com o fim de leválos para território estrangeiro.

Pena - detenção, de 1 (um) a 3 (três) anos e multa.

Já o art. 207 do Código Penal estabelece o crime de aliciamento de trabalhadores de um local para outro do território nacional, no seguinte sentido:

Art. 207. Aliciar trabalhadores, com o fim de levá-los de uma para outra localidade do território nacional:

Pena - detenção de um a três anos, e multa.

$\S 1^{\circ}$ Incorre na mesma pena quem recrutar trabalhadores fora da localidade de execução do trabalho, dentro do território nacional, mediante fraude ou cobrança de qualquer quantia do trabalhador, ou, ainda, não assegurar condições do seu retorno ao local de origem. 
§2ำ A pena é aumentada de um sexto a um terço se a vítima é menor de dezoito anos, idosa, gestante, indígena ou portadora de deficiência física ou mental.

Recordamos que na Constituição de 1988 há indicação da competência para julgar os supracitados crimes:

Art. 109. Aos juízes federais compete processar e julgar: [...]

$\mathrm{VI}-[\ldots]$ os crimes contra a organização do trabalho [...].

Com a Emenda Constitucional no 45, de 31.12.2004, houve a extensão da competência para a Justiça do Trabalho.

A suspensão condicional do processo é encontrada no art. 89 da Lei no 9.099/1995 (Lei dos Juizados Especiais), ${ }^{48}$ e é aplicável a todos os crimes que possuem pena igual ou inferior a um ano:

Art. 89. Nos crimes em que a pena mínima cominada for igual ou inferior a um ano, abrangidas ou não por esta Lei, o Ministério Público, ao oferecer a denúncia, poderá propor a suspensão do processo, por dois a quatro anos, desde que o acusado não esteja sendo processado ou não tenha sido condenado por outro crime, presentes os demais requisitos que autorizariam a suspensão condicional da pena (art. 77 do Código Penal).

Antes de adentrarmos à questão envolvendo o direito internacional do trabalho, convém frisar que a mesma Emenda Constitucional no 45, de 2004, inseriu, entre tantas outras modificações, o §3ำ no art. 5ํ,ำ da Constituição de 1988, como comentado por Marco Antônio César Villatore e Eduardo Biacchi Gomes: ${ }^{50}$ "O foco principal do supracitado texto é a análise da hierarquia das Convenções Fundamentais da OIT, que serviram de base para as Declarações da própria Organização, além do MERCOSUL, as duas firmadas no ano de 1998”.

48 BRASIL. Lei no 9.099, de 26 de setembro de 1995. Disponível em: <http://www.planalto.gov.br/ccivil_03/ Leis/L9099.htm>. Acesso em: 8 set. 2017.

49 Art. 5, §3: "Os direitos e garantias expressos nesta Constituição não excluem outros decorrentes do regime e dos princípios por ela adotados, ou dos Tratados Internacionais em que a República Federativa do Brasil seja parte".

50 VILLATORE, Marco Antônio César; GOMES, Eduardo Biacchi. Hierarquia das Convenções Fundamentais da Organização Internacional do Trabalho na conformidade da Emenda Constitucional 45, 31 de dezembro de 2004. In: RAMOS FILHO, Wilson (Org.). Constituição e competência material da Justiça do Trabalho depois da EC 45/2004. Curitiba: Genesis, 2005. p. 97-98. 
Das oito convenções classificadas pela OIT como fundamentais, encontramse: sobre trabalho forçado ( $n^{\circ} 29$ e no 105); sobre discriminação no trabalho ( $n^{\circ}$ 100 e no 111); sobre negociação e liberdade sindicais (no 87 e no 98) e sobre trabalho infantojuvenil ( $n$ - 138 e $n \div$ 182), a maioria ratificada pelo Brasil, mas com aplicação de lei ordinária, salvo a Convenção no 138 da OIT, podem ter modificada a sua caracterização para emenda constitucional.

Apenas a Convenção no 87 da OIT, sobre liberdade sindical, não foi ratificada pelo nosso país, em razão da unicidade contratual e da contribuição sindical obrigatória, mas que passará a ser facultativa, a partir do dia 11.11.2017, quando entrará em vigor a Lei no 13.467/2017 (Reforma Laboral). ${ }^{51}$

Naquele mesmo estudo ${ }^{52}$ continua a explicação:

Com essa transformação, tais importantes instrumentos terão força constitucional, não ficando ao alvitre do surgimento de nova legislação que ocasionaria a sua derrogação, na parte que fosse conflitante com os mesmos.

Ganha maior relevância a questão, quando depararmos com os Tratados decorrentes de Direitos Humanos que, a partir da Emenda Constitucional 45/04, desde que aprovados por 3/5, em dois turnos em cada uma das Casas do Congresso Nacional, passam a ter o mesmo tratamento de emenda à constituição.

O primeiro autor, em outro estudo, ${ }^{53}$ já comentou:

Dentre as 183 Convenções da Organização Internacional do Trabalho, aprovadas até junho de 2001, “as deliberações da estrutura tripartite da OIT designaram oito como fundamentais, as quais integram a Declaração de Princípios Fundamentais e Direitos no Trabalho da OIT (1998)".

Lembramos que, em "10 de dezembro de 1998, durante a 15a. Reunião Ordinária, foi firmada, no Rio de Janeiro, a Declaração

51 BRASIL. Lei no 13.467, de 13 de julho de 2017. Disponível em: <http://www.planalto.gov.br/ccivil_03/_ ato2015-2018/2017/lei/L13467.htm>. Acesso em: 30 ago. 2017.

52 VILLATORE, Marco Antônio César; GOMES, Eduardo Biacchi. Hierarquia das Convenções Fundamentais da Organização Internacional do Trabalho na conformidade da Emenda Constitucional 45, 31 de dezembro de 2004. In: RAMOS FILHO, Wilson (Org.). Constituição e competência material da Justiça do Trabalho depois da EC 45/2004. Curitiba: Genesis, 2005. p. 97-98.

53 Organização Internacional do Trabalho: Escritório no Brasil. OIT. Disponível em: <www.ilo.org/public/ portugue/region/ampro/brasilia/rules/organiza.htm> apud VILLATORE, Marco Antônio César. Direito do trabalho no MERCOSUL e nas Constituições dos Estados partes. Revista de Derecho Internacional y del MERCOSUR, Buenos Aires, v. 5, n. 5, p. 49-66, 2004. Grifos no original. 
Sociolaboral do MERCOSUL, sendo subdividida nas seguintes partes: Direitos Individuais; Direitos Coletivos; Outros Direitos e, por último, Aplicação e Seguimento, sendo que "esse importante documento surgiu por meio de sugestões das Centrais Sindicais e do próprio Subgrupo de Trabalho n. 10, tendo por base as oito Convenções Internacionais da Organização Internacional do Trabalho denominadas fundamentais e que deveriam ser ratificadas por todos os países".

As convenções especiais de abolição do trabalho forçado, da Organização Internacional do Trabalho, são as de no 29, de 1930, em vigência no Brasil desde 25.4.1958, e de no 105, de 1957, em vigência no nosso país a partir de 18.6.1966, com o mesmo título e com apenas 2 (dois) artigos.

A primeira foi provada na 14ํㅗ Reunião da Conferência Internacional do Trabalho, em Genebra, no ano de 1930, entrando em vigor internacionalmente no ano de 1932, sendo que o seu primeiro artigo estabelece o compromisso dos Estados-membros de suprimir a utilização de trabalho forçado ou obrigatório em mais curto espaço de tempo possível.

Trabalho forçado ou obrigatório, conforme o art. $2^{\circ}$ da supracitada convenção, é todo o trabalho ou serviço realizado sob ameaça de qualquer punição ou que não seja espontâneo.

Encontramos as seguintes exceções: a) serviço militar obrigatório; b) trabalho ou serviço para obrigações cívicas; c) pena alternativa; d) caso de força maior; e) trabalho ou serviço realizado para a comunidade.

Por último, interessante comentar o art. 26 que estabelece os territórios em que seria aplicável a convenção supracitada, nos seguintes termos: a) territórios aplicáveis; b) territórios aplicáveis, mas com modificação, devendo haver explicação para tal diferenciação; c) territórios em que o Estado-membro se reserva de aplicar.

Em 9.11.2016 entrou em vigência o protocolo relativo à Convenção no 29, de 1930, sobre trabalho forçado, que foi adotado como uma recomendação em 11.6.2014, pela Organização Internacional do Trabalho, na ocasião da centésima terceira sessão da Conferência Internacional do Trabalho. ${ }^{54}$

Matteo Carbonelli comentou o protocolo supracitado, da seguinte forma:

O protocolo menciona em primeira mão, entre as medidas de prevenção para adotar: a educação e a informação das pessoas, que devem ser conduzidas, como afirma a recomendação, através de

54 PROTOCOLO da OIT sobre trabalho forçado entra em vigor. OIT, 9 nov. 2016. Disponível em: <http://www. ilo.org/brasilia/noticias/WCMS_534585/lang-pt/index.htm>. Acesso em: 30 ago. 2017. 
campanhas para sensibilização, seja para as pessoas consideradas de maior risco, ao fim de evitar que se tornem vítimas de trabalho forçado, informando de seus direitos e como podem obter uma assistência em caso de necessidade, seja para os empregadores para evitar que se encontrem implicados em práticas de trabalho forçado, prevendo que também as pessoas jurídicas possam ser entendidas responsáveis de recorrer ao trabalho forçado, pondo a ênfase sobre as sanções em casos do gênero e com orientação e sustentação em seu favor para que possam prevenir e atenuar os riscos de trabalho forçado. ${ }^{55}$

O mesmo protocolo finaliza afirmando:

para assegurar uma melhor realização de tais objetivos, prevê-se enfim um reforço da cooperação internacional entre os Estados, e, em particular, entre as instituições encarregadas da aplicação da legislação do trabalho e daquela penal, com uma mútua assistência judiciária, além de a troca de informações e a condivisão de boas práticas, a fim da prevenção e da eliminação de todas as formas de trabalho forçado ou obrigatório. ${ }^{56}$

A Convenção no 105 da OIT, complementação da anterior, foi aprovada na 40a Reunião da Conferência Internacional do Trabalho, em Genebra, no ano de 1957, entrando em vigor internacionalmente no ano de 1959.

O seu art. 1ํe estabelece o compromisso dos Estados-membros em suprimir o trabalho forçado ou obrigatório através dos seguintes meios: a) coerção ou sanção por oposição ideológica à ordem política, social ou econômica estabelecida; b) método de mobilização e de utilização de mão de obra para fim de desenvolvimento econômico; c) como medida de disciplina de trabalho; d) como punição por participação em greve; e) como medida de discriminação racial, social, nacional ou religiosa.

O art. 2ำ da Convenção no 105 da OIT prevê o compromisso dos Estadosmembros que a ratificarem de abolir imediatamente o trabalho forçado ou obrigatório.

55 Informação verbal de Matteo Carbonelli, denominada O Protocolo da Organização Internacional do Trabalho Contra as Novas Formas de Trabalho Forçado, em apresentação no Grupo de Pesquisa Neates, coordenado por Marco Antônio César Villatore, da PUCPR, em fevereiro de 2017.

56 PROTOCOLO da OIT sobre trabalho forçado entra em vigor. OIT, 9 nov. 2016. Disponível em: <http://www. ilo.org/brasilia/noticias/WCMS_534585/lang-pt/index.htm>. Acesso em: 30 ago. 2017. 
Outra convenção indireta é a de № 95, sobre proteção do salário, em vigência nacional a partir de 25.4.1958, determinando que o salário seja pago em intervalos regulares e condenando os modos de pagamento que privem o trabalhador de toda a possibilidade real de deixar o seu emprego.

Foi aprovada, em 10.12.1948, a Declaração Universal dos Direitos dos Homens, estabelecendo, em seu art. IV, que "ninguém será mantido em escravidão ou servidão; a escravidão e o tráfico de escravos serão proibidos em todas as suas formas" e, em seu art. V, que "ninguém será submetido à tortura, nem a tratamento ou castigo cruel, desumano ou degradante".

A Convenção das Nações Unidas sobre Escravidão, de 1926, estabeleceu regras proibitivas nesse sentido, recebendo emendas por meio do protocolo de 1953. Além disso, foi firmada, em 1956, a Convenção Suplementar sobre Abolição da Escravidão.

Já o Conselho de Direitos Humanos é o órgão intergovernamental criado pelos Estados-membros da ONU com o objetivo de reforçar a promoção e a proteção dos direitos humanos em todo o mundo, substituindo a Comissão de Direitos Humanos das Nações Unidas em 2006, sendo um órgão subsidiário da AG-ONU. "O Conselho trabalha de forma muito próxima com o Alto Comissariado dos Direitos Humanos e participa dos 'Procedimentos Especiais' da ONU”. ${ }^{57}$

A brasileira Raquel Roinik foi uma Special Rapporteur sobre o Direito de Habitação Adequada como Componente do Direito ao Padrão de Vida Adequado e ao Direito da Não Discriminação nesse contexto. ${ }^{58}$

Também sobre idêntico tema na Organização das Nações Unidas foi aprovado, na 62 ${ }^{\text {a }}$ Reunião, em 23.3.2016, o HRC/31/L.10.59

Aproveitando os temas supracitados, deve-se ter atenção especial a este aspecto, pois atualmente é difícil de se encontrar um trabalho escravo típico, sendo mais comum, infelizmente, o trabalho análogo à escravidão, em que o trabalhador se encontra em local não apropriado, inclusive residindo nele.

Já o HRC/31/ L.26/Rev., da 64ª Reunião da ONU, de 24.3.2016, de noos 31 e 32, dispõe sobre a proteção dos defensores dos direitos humanos, sejam

57 GIFFONI, Manoel. Conselho de Direitos Humanos - ONU. Wordpress, 17 mar. 2010. Disponível em: <https://fichasmarra.wordpress.com/2010/03/17/conselho-de-direitos-humanos-onu/>. Acesso em: 7 set. 2017.

58 ONU. $31^{\text {st }}$ session of the Human Rights Council (29 February - 24 March 2016). Disponivel em: <http:// www.ohchr.org/EN/HRBodies/HRC/RegularSessions/Session31/Pages/ResDecStat.aspx>. Acesso em: 7 set. 2017.

59 GIFFONI, Manoel. Conselho de Direitos Humanos - ONU. Wordpress, 17 mar. 2010. Disponível em: <https://fichasmarra.wordpress.com/2010/03/17/conselho-de-direitos-humanos-onu/>. Acesso em: 7 set. 2017. 
indivíduos, grupos ou órgãos da sociedade, abordando os direitos econômicos, sociais e culturais. ${ }^{60}$

O Fórum Social Mundial tem discutido muito sobre a eliminação de todas as formas de privação da liberdade do trabalhador, mas, infelizmente, o número de trabalhadores em regime análogo ao de escravidão tem crescido assustadoramente, demonstrando que há muito a realizar ainda.

Sabemos que uma parte dos trabalhadores resgatados, após um período, maior ou menor, retorna a uma situação similar, quando não resgatado novamente.

Toda a sociedade deve se conscientizar que, enquanto não tivermos um aumento no número de empregos formais, esses trabalhadores menos qualificados se sentirão atraídos por propostas de uma relação de emprego que, por vezes, redundará em uma situação de privação da sua liberdade, às vezes atraídos por amigos e até por familiares.

Há uma série de dúvidas com relação a se Lei no 13.467, de 13.7.2017 (denominada Reforma Laboral) resolverá, ao menos momentaneamente, tal problema, com as figuras modificadas do trabalho temporário, da terceirização e do teletrabalho, e novidades como o trabalho intermitente. ${ }^{61}$

Para tanto, é necessário conhecer, compreender, discutir e encontrar soluções possíveis para a defesa dos trabalhadores, dos seres humanos, que, por ignorância ou necessidade, acabam sendo vítimas de traficantes, exploradores da humanidade.

Assim, é preciso um esforço coletivo para o reconhecimento dos direitos fundamentais que o trabalhador conquista em relações verdadeiramente democráticas e dignas de serem vividas, que deem à "vida" todo o seu significado, a sua amplitude de beleza e de prazer.

Problema atual é a diminuição de investimentos pelo Governo Federal em razão da crise econômica no Brasil, como comentado a seguir:

O eventual sucateamento do Ministério do Trabalho e a afronta à proteção do trabalho.

A mitigação da fiscalização contra a escravidão inclina-se a permitir ou facilitar a violação de incontáveis incisos do artigo $7^{0}$ da Constituição da República Federativa do Brasil de $1988 .{ }^{62}$

60 GIFFONI, Manoel. Conselho de Direitos Humanos - ONU. Wordpress, 17 mar. 2010. Disponível em: <https://fichasmarra.wordpress.com/2010/03/17/conselho-de-direitos-humanos-onu/>. Acesso em: 7 set. 2017.

61 BRASIL. Lei no 13.467, de 13 de julho de 2017. Disponível em: <http://www.planalto.gov.br/ccivil_03/_ ato2015-2018/2017/lei/L13467.htm>. Acesso em: 30 ago. 2017.

62 TEMER e o trabalho escravo: corte de gastos impede a fiscalização contra o trabalho escravo. Jusbrasil. 2017. Disponível em: <https://ebradi.jusbrasil.com.br/artigos/480339628/temer-e-o-trabalho-escravocorte-de-gastos-impede-a-fiscalizacao-contra-o-trabalho-escravo?ref=topic_feed>. Acesso em: 30 ago. 2017. 
O Brasil, portanto, é um dos países com maior número de regras sobre este importante tema do gênero "trabalho forçado", como definido pela Organização Internacional do Trabalho.

\section{Considerações finais}

Motivo de ampla legislação, de estudos e de duas comissões parlamentares de inquérito, no congresso federal, o tema do tráfico humano não poderia ser analisado em situação mais interessante, pois o Brasil sediou alguns grandes eventos que trouxeram milhares de estrangeiros, como a Copa das Confederações, em 2013, a Copa do Mundo de Futebol, em 2014 e as Olimpíadas, no ano de 2016, e, em oportunidades como essas, há a facilitação de atividades ligadas ao comércio irregular.

Urge a necessidade de que ascenda a luta contra a indiferença ao tráfico de pessoas, bem como para a ocorrência de intervenção dos Estados Nacionais, na formação de uma força tarefa global, para a defesa da vida dos trabalhadores e para o respeito aos direitos humanos, aos direitos fundamentais e aos princípios orientadores do Estado Democrático de Direito.

O tema em questão guarda nítida relação com os direitos econômicos (circulação de riquezas e desenvolvimento) e os direitos fundamentais (necessidade de proteção dos direitos sociais dos referidos trabalhadores).

Foi também analisada a importância da harmonização das regras trabalhistas, com especial atenção àquelas referentes às principais convenções internacionais da Organização Internacional do Trabalho, como forma de dar maior eficácia aos referidos direitos, que podem ser caracterizados como econômicos e fundamentais.

Não resta dúvida de que para enfrentar o tráfico humano e o trabalho escravo ou em situação análoga à escravidão é preciso repensar a globalização e a precarização das relações de trabalho, as políticas migratórias, as desigualdades de classes, a realidade da prostituição. Há de se ter consciência que o enfrentamento do tráfico e do trabalho escravo ou em situação análoga à escravidão exige uma proteção integral aos trabalhadores.

Para tanto, é preciso romper com o passado, com o desrespeito ao ser humano trabalhador, desde sempre marginalizado e oprimido, para a construção de uma nova ordem, uma nova sociedade, um novo ser humano - mais humano -, mais consciente de si e do outro, um ser completo e fraterno.

É utopia? Talvez, mas o que seria da humanidade se não fossem os sonhadores... 
Human trafficking and slave labor in light of the guarantee of fundamental rights front - Right to work

Abstract: The focus of this study is human trafficking and slave labor in light of the guarantee of fundamental rights, with the purpose of investigating their real situation in relation to social problems and legislative issues. The method chosen was inductive - bibliographical and document-based. The trafficking in persons with the motive to exploit them for slave labor is a violation of human dignity, a negation of fundamental rights, and a disregard of the democratic rule of law, and is a practice that greatly troubles both national societies and international organs. Thus it is necessary to confront this "sore" that cannot be forgotten and then to raise social consciousness about the necessity to eliminate various forms of discrimination, confront problems of prostitution, promote descent work, and create responsible immigration policies, aiming at the Right to Work. It is important to develop public policies seeking to make fundamental rights efficacious and to transform social structures to achieve a just and egalitarian society.

Keywords: Fundamental rights. Human trafficking. Slave labor. Right to work.

Summary: 1 Introduction - 2 Human trafficking and slave labor - unforgettable sore - $\mathbf{3}$ Social problems and legislative issues - 4 Final considerations - $\mathbf{5}$ Explanatory notes and references

\section{Referências}

21 milhões de pessoas são vítimas de trabalho forçado no mundo. OIT, 1ํ jun. 2012. Disponível em: <http://www.oitbrasil.org.br/node/846>. Acesso em: 30 ago. 2017.

ABREU, Lília Leonor; ZIMMERMANN, Deyse Jacqueline. Trabalho escravo contemporâneo praticado no meio rural brasileiro. Abordagem sócio-jurídica. Revista do Tribunal Regional do Trabalho da 12ª Região, v. 12, n. 17, p. 105-120, jan./jun. 2003.

ABREU, Raíssa. CPI do tráfico de pessoas aprova relatório final com proposta de mudança na lei penal. Senado Notícias, 19 dez. 2012. Disponível em: <http://www12.senado.gov. $\mathrm{br} /$ noticias/materias/2012/12/19/cpi-do-trafico-de-pessoas-aprova-relatorio-final>. Acesso em: 30 ago. 2017.

ALICIAR jogadores é equiparado a traficar pessoas. Conjur, 11 dez. 2012. Disponível em: <http://www.conjur.com.br/2012-dez-11/tj-paulista-condena-portuguesa-santista-traficopessoas>. Acesso em: 30 ago. 2017.

ALMEIDA, Ronald Silka; VILLATORE, Marco Antônio César. A encíclica rerum novarum e sua importância em relação à Organização Internacional do Trabalho. In: GUNTHER, Luiz Eduardo; VILLATORE, Marco Antônio César (Org.). Rerum novarum. Estudos em homenagem aos 120 anos da encíclica papal. Curitiba: Juruá, 2011.

ARRUDA, Kátia Magalhães. Trabalho análogo à condição de escravo: um ultraje à Constituição. Gênesis Revista de Direito do Trabalho, v. 6, n. 36, p. 683-689, dez. 1995.

BONAVIDES, Paulo. Curso de direito constitucional. 16. ed. São Paulo: Malheiros, 2005.

BRASIL. Lei no 11.948, de 16 de junho de 2009. Disponível em: <http://www.planalto.gov. br/ccivil_03/_ato2007-2010/2009/lei/l11948.htm>. Acesso em: 30 ago. 2017.

BRASIL. Lei no 13.344, de 06 de outubro de 2016. Disponível em: <http://www.planalto. gov.br/ccivil_03/_ato2015-2018/2016/lei/L13344.htm>. Acesso em: 30 ago. 2017. 
BRASIL. Lei no 13.467, de 13 de julho de 2017. Disponível em: <http://www.planalto.gov. br/ccivil_03/_ato2015-2018/2017/lei/L13467.htm>. Acesso em: 30 ago. 2017.

BRASIL. Lei no 9.099, de 26 de setembro de 1995. Disponível em: <http://www.planalto. gov.br/ccivil_03/Leis/L9099.htm>. Acesso em: 8 set. 2017.

BRASIL. Ministério do Trabalho e Emprego. Manual de combate ao trabalho em condições análogas às de escravo. Brasília: Ministério do Trabalho e Emprego, 2011. Disponível em: <http://www.mpf.mp.br/atuacao-tematica/ccr2/coordenacao/comissoes-e-grupos-detrabalho/escravidao-contemporanea-migrado-1/notas-tecnicas-planos-e-oficinas/combate\%20 trabalho\%20escravo\%20WEB\%20MTE.pdf>. Acesso em: 7 set. 2017.

BRASIL. Portaria Interministerial MTE/SEDH no 02, de 12 de maio de 2011. Disponível em: <http://www.normaslegais.com.br/legislacao/portariainter_mtesedh02_2011.htm>. Acesso em: 30 ago. 2017.

BRASIL. Portaria no 447, de 19 de setembro de 2014. Disponível em: <file:///Users/ VILLATORE/Downloads/0447_Portaria_n._447_Institui_o_GEFM_-_Trabalho_Escravo.pdf>. Acesso em: 30 ago. 2017.

BRASIL. Presidência da República. Decreto no 5.015/2004. Promulga o Protocolo Contra Contrabando de Migrantes por Terra, Mar e Ar, Complemento à Convenção das Nações Unidas Contra o Crime Organizado Transnacional. Disponível em: <http://www.planalto. gov.br/ccivil_03/_Ato2004-2006/2004/Decreto/D5016.htm>. Acesso em: 30 ago. 2017.

BRASIL. Quadro das operações de fiscalização para erradicação do trabalho escravo - SIT/ SRTE. 2016. Disponível em: <file:///Users/VILLATORE/Downloads/2694_RN-122.pdf>. Acesso em: 30 ago. 2017.

BRASIL. Resolução normativa no 122, de 03 ago. 2016. Disponível em: <file:///Users/ VILLATORE/Downloads/Quadro_Resumo_2016por_UF_para_internet.pdf >. Acesso em: 30 ago. 2017.

CÂMARA DOS DEPUTADOS. Comissão Parlamentar de Inquérito. Trabalho escravo CPITRAES. Disponivel em: <//www2.camara.leg.br/atividade-legislativa/comissoes/ comissoes-temporarias/parlamentar-de-inquerito/54a-legislatura/cpi-trabalho-escravo/ conheca-a-comissao/apresentação>. Acesso em: 30 ago. 2017.

CANOTILHO, José Joaquim Gomes. Direito constitucional e teoria da Constituição. 3. ed. Coimbra: Almedina, 1998.

CARVALHO, Luciana Paula Vaz de. A violação à dignidade da criança e do adolescente no trabalho infantil. Normas e ações de proteção. In: PIOVESAN, Flavia; CARVALHO, Luciana Paula Vaz de (Org.). Direitos humanos e direito do trabalho. São Paulo: Atlas, 2010.

COSTA, Ângela Marques da; SCHWARCZ, Lilia Moritz. 1890 - 1914: no tempo das certezas. São Paulo: Companhia das Letras, 2000.

CPI - Tráfico nacional e internacional de pessoas no Brasil - CPITRAFPE. Senado Federal. Disponivel em: <http://www.senado.gov.br/atividade/Comissoes/comissao. asp?origem=\&com=1551>. Acesso em: 30 ago. 2017.

FÁVERO FILHO, Nicanor. Trabalho escravo: vilipendio à dignidade humana. In: PIOVESAN, Flavia; CARVALHO, Luciana Paula Vaz de (Org.). Direitos humanos e direito do trabalho. São Paulo: Atlas, 2010. 
FRANCO SOBRINHO, Manoel de Oliveira. Desapropriação. 2. ed. São Paulo: Saraiva, 1996. GIFFONI, Manoel. Conselho de Direitos Humanos - ONU. Wordpress, 17 mar. 2010. Disponível em: <https://fichasmarra.wordpress.com/2010/03/17/conselho-de-direitos-humanosonu/>. Acesso em: 7 set. 2017.

LEVANTAMENTO do CNJ revela 428 processos por tráfico de pessoas e trabalho escravo no País. Jusbrasil, 2013. Disponível em: <https://correio-forense.jusbrasil.com.br/ noticias/213310004/levantamento-do-cnj-revela-428-processos-por-trafico-de-pessoas-etrabalho-escravo-no-pais>. Acesso em: 30 ago. 2017.

MACHADO, Sidnei. Trabalho escravo e trabalho livre no Brasil - alguns paradoxos históricos do Direito do Trabalho. Revista da Faculdade de Direito da Universidade Federal do Paraná, n. 38, p. 151-158, jan./dez. 2003.

MINISTÉRIO DA JUSTIÇA. Política Nacional de Enfrentamento ao Tráfico de Pessoas. Brasília: Ministério da Justiça, 2007. Disponível em: <http://reporterbrasil.org.br/documentos/ cartilha_trafico_pessoas.pdf>. Acesso em: 30 ago. 2017.

MINISTÉRIO DO TRABALHO. Nota oficial sobre a Portaria no 1.129/2017. Disponível em: $<$ http://trabalho.gov.br/noticias/5122-nota-oficial-sobre-portaria-n-1-129-2017>. Acesso em: 31 out. 2017.

MINISTRA Rosa Weber suspende efeitos de portaria ministerial sobre trabalho escravo. Notícias STF, 24 out. 2017. Disponivel em: <www.stf.jus.br/portal/cms/verNoticiaDetalhe. asp?idConteudo=359907>. Acesso em: 31 out. 2017.

MIRAGLIA, Lívia Mendez Moreira. O combate ao trabalho escravo contemporâneo e a justiça do trabalho. In: SENA, Adriana Goulart de; DELGADO, Gabriela Neves; NUNES, Raquel Portugal (Coord.). Dignidade humana e inclusão social. Caminhos para a efetivação do direito do trabalho no Brasil. São Paulo: LTr, 2010.

ONU. 31 ${ }^{\text {st }}$ session of the Human Rights Council (29 February - 24 March 2016). Disponivel em: <http://www.ohchr.org/EN/HRBodies/HRC/RegularSessions/Session31/Pages/ ResDecStat.aspx>. Acesso em: 7 set. 2017.

PARO, Walter Roberto. Trabalho forçado e a Justiça do Trabalho. Revista do Tribunal Regional do Trabalho da 8a Região, v. 36, p. 101-122, jan./jun. 2003.

PIOVESAN, Flávia. Proteção judicial contra omissões legislativas. São Paulo: Revista dos Tribunais, 1995.

PROTOCOLO da OIT sobre trabalho forçado entra em vigor. OIT, 9 nov. 2016. Disponível em: <http://www.ilo.org/brasilia/noticias/WCMS_534585/lang-pt/index.htm>. Acesso em: 30 ago. 2017.

RODRIGUES, Vânia. Trabalho escravo: parecer será favorável ao confisco das terras. UITA Secretaría Regional Latinoamericana, Montevideo, 5 abr. 2004. Disponível em: <http:// www6.rel-uita.org/internacional/trabalho_escravo.htm>. Acesso em: 30 ago. 2017.

SAMPAIO, Rômulo Silveira da R.; VILLATORE, Marco Antônio César. A livre circulação de trabalhadores na Comunidade Europeia e no MERCOSUL. In: GOMES, Eduardo Biacchi; REIS, Tarcísio Hardman (Org.). Globalização e o comércio internacional no direito da integração. São Paulo: Lex, 2005. 
SARLET, Ingo Wolfgang. A eficácia dos direitos fundamentais: uma teoria geral dos direitos fundamentais na perspectiva constitucional. 10. ed. Porto Alegre: Livraria do Advogado, 2009.

SEIXAS, Kleyzer. Tráfico de pessoas é maior entre mulheres e crianças. A Tarde, 13 nov. 2012. Disponivel em: <http://atarde.uol.com.br/bahia/materias/1466971-trafico-depessoas-e-maior-entre-mulheres-e-criancas>. Acesso em: 29 jan. 2013.

SILVA, De Plácido e. Vocabulário jurídico. 18. ed. Rio de Janeiro: Forense, 2001.

SOUZA, Mércia Cardoso de; SILVA, Laura Cristina Lacerda e. Algumas reflexões sobre o enfrentamento ao tráfico de pessoas no Brasil. Âmbito Jurídico. Disponível em: <www.ambitojuridico.com.br/site/index.php?n_link=revista_artigo_leitura\&artigo_id=9302>. Acesso em: 30 ago. 2017.

TEMER e o trabalho escravo: corte de gastos impede a fiscalização contra o trabalho escravo. Jusbrasil. 2017. Disponivel em: <https://ebradi.jusbrasil.com.br/artigos/480339628/ temer-e-o-trabalho-escravo-corte-de-gastos-impede-a-fiscalizacao-contra-o-trabalhoescravo?ref=topic_feed>. Acesso em: 30 ago. 2017.

TRF4 - Justiça busca maior integração entre órgãos de combate ao trabalho escravo. Diário Indústria \& Comércio, 13 mar. 2017. Disponível em: <http://www.diarioinduscom.com/ trt4-justica-busca-maior-integracao-entre-orgaos-de-combate-ao-trabalho-escravo/>. Acesso em: 30 ago. 2017.

UNODC. UN.GIFT 2009. Disponivel em: <http://www.unodc.org/documents/humantrafficking/TIP_Executive_summaries.pdf>. Acesso em: 30 ago. 2017.

VILLATORE, Marco Antônio César. Direito do trabalho no MERCOSUL e nas Constituições dos Estados partes. Revista de Derecho Internacional y del MERCOSUR, Buenos Aires, v. 5, n. 5, p. 49-66, 2004.

VILLATORE, Marco Antônio César; GOMES, Eduardo Biacchi. Hierarquia das Convenções Fundamentais da Organização Internacional do Trabalho na conformidade da Emenda Constitucional 45, 31 de dezembro de 2004. In: RAMOS FILHO, Wilson (Org.). Constituição e competência material da Justiça do Trabalho depois da EC 45/2004. Curitiba: Genesis, 2005.

WANDELLI, Leonardo Vieira. O direito humano e fundamental ao trabalho. Fundamentação e exigibilidade. São Paulo: LTr, 2012.

Informação bibliográfica deste texto, conforme a NBR 6023:2002 da Associação Brasileira de Normas Técnicas (ABNT):

VILLATORE, Marco Antônio César; WüLFING, Juliana. Garantia dos direitos fundamentais frente ao tráfico humano e ao trabalho escravo - Direito ao trabalho. Direitos Fundamentais \& Justiça, Belo Horizonte, ano 11, n. 37, p. 67-104, jul./dez. 2017.

Recebido em: 14.03.2013

Pareceres: 02.07.2013, 27.08.2013, 23.06.2017

Aprovado em: 17.10.2017 